\title{
Türkiye’de STEM Eğitimi Üzerine Yapılan Araştırmaların Durumu Üzerine Bir Çalışma
}

\section{Pınar ÇAVAŞ*, Aslıhan AYAR**, Selin BULA TURUPLU*** ve Gizem GÜRCAN****}

Öz: İçinde bulunduğumuz 21. yüzyılda bilim ve teknoloji çok hızlı bir şekilde ilerlemektedir. Bilim ve teknolojideki bu değişim, çağımız insanlarının yaratıcılık, eleştirel düşünme, problem çözme, teknolojinin etkili kullanımı, bilgi yönetimi, işbirliği ve iletişim gibi farklı becerilere sahip olmasını zorunluluk haline getirmiştir. $\mathrm{Bu}$ becerilerin öğrencilere kazandırılabilmesi ve geliştirilebilmesi için bazı öğretim modellerine ihtiyaç vardır. STEM; Science (Fen bilimleri), Technology (Teknoloji), Engineering (Mühendislik) ve Mathematics (Matematik) alanlarının baş harflerinden oluşan ve bunların birbirlerine entegre edilmesi anlamına gelen bir öğretim yaklaşımıdır. Türkçeye FeTeMM şeklinde adapte edilen bu yaklaşım, öğrencilerin okulda öğrendikleri teorik bilgileri günlük hayata aktarabilmeleri, farklı disiplinleri bir bütün olarak ele alabilmeleri, bilginin yanında beceri kazanmayı da hedeflemektedir. Bu araştırmada 2010 yılından günümüze, STEM eğitimiyle ilgili ulusal alan yazında yapılmış makale ve lisansüstü tezlerin incelenmesi amaçlanmıştır. $\mathrm{Bu}$ amaç kapsamında YÖK Ulusal Tez Merkezi veri tabanında bulunan, 2010-2018 yıllarına ait ve anahtar kelimelerinde "STEM, STEM eğitimi, FeTeMM, entegre STEM öğretimi” terimlerini içeren toplam 45 lisansüstü tez incelenmiştir. Makalelerin seçiminde ise TÜBİTAK ULAKBİM-DergiPark veri tabanında bulunan eğitimle ilgili 64 dergi listelenmiş ve bu dergilerde 2010-2018 yılları arasında yayınlanan, yine aynı anahtar kelimeleri içeren 52 makale araştırma kapsamına alınmıştır. Araştırmalar, yayınlandıkları yıl, yayın dili, çalışılan bağımlı değişkenler, kullanılan yöntemler, veri toplama araçları, örneklem grupları ve veri analizi yöntemleri bakımından detaylı bir şekilde analiz edilmiştir. Bu araştırmadan elde edilen bulgularla, ülkemizde STEM eğitimiyle ilgili yapılan çalışmalara genel bir bakış kazandırılması ve yapılacak yeni çalışmalara 1şık tutması beklenmektedir.

Anahtar Kelimeler: STEM, içerik analizi, fen eğitimindeki eğilimler

\footnotetext{
* Doç. Dr., Ege Üniversitesi, Eğitim Fakültesi, Temel Eğitim Bölümü, Email:pinarcavas@gmail.com Orcid No: 0000-00019492-9002

** Yüksek Lisans Öğrencisi, Ege Üniversitesi, Eğitim Bilimleri Enstitüsü, Email:aslihanayar96@gmail.com Orcid No: 00000002-1137-4679

*** Yüksek Lisans Öğrencisi, Ege Üniversitesi, Eğitim Bilimleri Enstitüsü, Email:selinbula07@gmail.com Orcid No: 00000003-0946-2626

**** Yüksek Lisans Öğrencisi, Ege Üniversitesi, Eğitim Bilimleri Enstitüsü, Email:gizemgurcan1994@gmail.com Orcid No: 0000-0003-0946-2626
}

Gönderim:26.10.2019 Kabul:17.01.2020 Yayın:15.06.2020




\section{A Study on the Status of STEM Education Research in Turkey}

Abstract: Science and technology have been changed very rapidly in the 21st century. This change in science and technology has made it necessary for people to gain different skills. These skills can be listed as creativity, critical thinking, problem solving and effective usage of technology, information management, cooperation and communication. Some teaching models are needed to enable students to acquire and develop these skills. STEM is an acronym for the fields of Science, Technology, Engineering and Math; and includes effective integration of them STEM education, which aims to enable students to transfer the theoretical knowledge that they learn in school to daily life, to handle different disciplines as a whole and to gain skills along with knowledge, has started to become popular recently. In this study, it is aimed to examine the articles and graduate theses in national literature about STEM education since 2010. Within the scope of this aim of the study, 45 master and doctoral theses and 52 journal articles which are reached from the national academic data base (ULAKBIM) and Higher Education Institution National Thesis Centre (YÖK) were selected for analysis. The studies were analyzed in terms of publication year, the language of publication, research methods, dependent variables, data collection tools, sampling groups, data analysis methods and represented with tables. With the findings of this research, it is expected to give an overview of the studies on STEM education in our country and to shed light on the new studies.

Keywords: STEM, Content analysis, Trends in science education

\section{Giriş}

Günümüz dünyasında her alanda kendini hissettiren çok hızlı değişim ve gelişmeler yaşanmaktadır. Özellikle bilim ve teknoloji alanlarında yaşanan bu hızlı ilerleyiş toplumlarda değişikliği de beraberinde getirmiştir. Bu değişimler özellikle sağlık, ekonomi, sanat, iletişim ve eğitim gibi birçok alanı da doğrudan etkilemiştir. Söz konusu alanlarda sürekli yeni buluşlara imza atılırken, teknoloji yaşamımızın her alanına girmektedir. Bilim ve teknolojide meydana gelen bu hızlı değişimler ülkeler arası rekabeti arttırmıştır. Ülkelerin uluslararası alanda söz sahibi olabilmesi için bireylerin de farklı becerilere sahip olması zorunluluk haline gelmiştir. 21. yüzyıl becerileri olarak adlandırılan bu beceriler yaratıcı ve eleştirel düşünme, problem çözme, bilimsel süreç becerilerine sahip olma, takım olarak işbirliği içinde çalışabilme olarak sıralanabilir (Akgündüz, Ertepınar, Ger, Kaplan Sayı ve Türk, 2015). Bu becerilere sahip bireyler yetiştirmek, ülkelerin ekonomik ve teknolojik gelişmelere ayak 
uydurabilmesi için gereklidir. Günümüz meslekleri de bu beceriler çerçevesinde şekillenmektedir. Bu nedenle, erken çocukluk döneminden itibaren bu becerilerin çocuklara kazandırılması oldukça önemlidir.

21. yüzyıl becerilerinin bireylere kazandırılmasına yönelik ihtiyaçlar, ülkelerin eğitim sistemlerinde yeniliklere gidilmesine neden olmuş, çeşitli öğretim yöntem ve yaklaşımları kullanılmaya başlanmıştır. STEM eğitimi birçok alan ve beceriyi kapsaması sayesinde bu yeni yaklaşımlar içerisinde öne çıkan bir yaklaşım olarak yerini almıştır. Matematik, teknoloji, mühendislik ve fen alanlarını tek çatı altında toplayıp bütünleştiren STEM eğitimi 21. yüzyıl becerilerinin kazandırılmasında etkin rol oynamaktadır (Akgündüz, Aydeniz, Çakmakçı, Çavaş, Çorlu, Öner ve Özdemir, 2015).

STEM terimi, orijinal dilinde science (fen), technology (teknoloji), engineering (mühendislik) ve mathematics (matematik) alanlarının baş harflerinin bir araya gelmesinden meydana gelmektedir. Ülkemizde FeTeMM (Fen, Teknoloji, Mühendislik, Matematik) olarak da adlandırılmaktadır. STEM; fen, teknoloji, matematik ve mühendislik alanlarının içerdiği bilgi ve becerilerin bütünleştirilmesi yoluyla, öğrencilere iletişim kurma, takım çalışması yapma, yaratıcı düşünebilme, araştırma yapma, sorgulama, üretme ve günlük hayat problemlerini çözebilme gibi birtakım becerilerin kazandırılmasını amaçlayan disiplinler arası bir eğitim yaklaşımıdır (Tezel ve Yaman, 2017). Böylece disiplinler arası ayrımın kaldırılması ve okul öncesinden üniversiteye kadar sorgulayan, araştıran, üreten ve yeni buluşlar yapabilen bir nesil yetiştirilmesi amaçlanmaktadır (Daşdemir, Cengiz ve Aksoy, 2018). STEM eğitiminin bir diğer amacı; farklı kademelerde eğitim alan meraklı, sorgulayıcı, yetenekli ve farklı becerilere sahip öğrencilerin belirlenerek, bu öğrencilerin üniversitelerde STEM alanlarına yönlendirilmesine olanak vermektir (Daşdemir vd., 2018). Amerika'da Ulusal Mühendislik Akademisi (National Academy of Engineering [NAE]) ve Ulusal Araştırma Konseyi’nin (National Research Council [NRC]) (2014) yayımladığı K-12 STEM eğitim raporuna göre, STEM eğitiminin üç temel amaca hizmet etmesi gerekmektedir. Bu amaçlar STEM alanlarında kariyer yapmaya yönlendirmek, STEM okuryazarlığını gerçekleştirmek, STEM iş alanlarına katılımı arttırmak ve yaygınlığını kazandırmak olarak sıralanabilir.

STEM eğitimi yeni bir kavram olmasına rağmen, pek çok gelişmiş ülke bu alanda proje ve programlar geliştirmeye ve sınıf içerisinde uygulamalarını yapmaya başlamıştır (Çiftçi, 2018). STEM uygulamaları ülkeden ülkeye farklılık göstermektedir. Günümüzde Amerika, İngiltere, Almanya, Avusturya, Finlandiya, Güney Kore, Çin, Avustralya ve 
Brezilya gibi dünyanın birçok ülkesi STEM eğitimine önem vermektedir (Çiftçi, 2018; Milli Eğitim Bakanlığı [MEB], 2018; Tabar, 2018).

STEM eğitimi ilk olarak ABD'de ortaya çıkmıştır. ABD'de Barack Obama 2010 yılında yaptığı bir konuşmada, Amerika'nın şu anki ekonomik gücünü koruması için STEM eğitimine yeterli önemin verilmesi gerektiğini; özellikle de fen, teknoloji, mühendislik ve matematik alanlarında yetişmiş birey sayısının arttırılması gerektiğini vurgulamıştır (Akgündüz, Aydeniz vd., 2015). NRC (2014) tarafindan Amerika'daki K-12 STEM eğitiminde; STEM alanlarında ileri düzey eğitimi ve kariyer alanlarını arttırmak, STEM becerilerine sahip iş gücünü geliştirmek ve tüm öğrencilerde fen okuryazarlığını arttırmak hedeflenmiştir. Bu hedefler çerçevesinde ABD’de birçok STEM eğitim merkezi kurulmuştur. 21. yüzyıl süresince de dünyadaki liderliğini sürdürmek isteyen $A B D$, bu amaçla kurulmuş olan STEM okullarına ve bu okulları içinde barındıran STEM okul sistemine ayrı bir önem vermektedir (Akgündüz, Aydeniz vd., 2015). Güney Kore’de Lee ve Park (2010) ilkokul öğrencileriyle yaptıkları araştırmada, öğrencilerin bilim insanı ve mühendisliğe yönelik doğru algılara sahip olmadığını bulmuş, bu nedenle onların erken yaştan itibaren teknoloji ve mühendislikle uğraşmalarının bilim insanı ve mühendisliğe dair algılarının değişebileceğini düşünmektedirler. Bu nedenlerden dolayı STEAM eğitimi Güney Kore eğitim sisteminde hayati bir konu olmaya başlamıştır (akt. Yakman ve Lee, 2012). Güney Kore, Amerika’dan farklı olarak STEM eğitimi kapsamında yer alan alanlara sanat (art) alanını da ekleyerek, fen, teknoloji, mühendislik, matematik ve sanat alanlarının entegre edilmesiyle oluşturulan STEAM'ı ortaya çıkarmıştır. STEAM yaklaşımı ile daha yaratıcı ve özgün ürünlerin ortaya çıkarılması beklenmektedir (Çiftçi, 2018).

Türkiye’de 2015 yılı ve öncesinde STEM eğitimine yönelik Millî Eğitim Bakanlığı tarafından hazırlanan stratejik bir eylem planı bulunmamaktadır. Türk Sanayi ve İş Adamları Derneği-TÜSİAD (2014) yayınladığı raporda, STEM alanında çalışanlar ile STEM dışı alanlarda çalışanların şirket alan katkılarında farklılık olduğu gözlemlenmiştir. Rapor sonucunda STEM alanlarına yönelik istihdam oluşturma, STEM alanlarında eğitim görecek öğrenci sayısının arttırılması ve eğitimin her kademesinde öğrencilerin STEM becerilerinin arttırılmasına yönelik bir planlamanın yapılması gerektiği belirtilmiştir. Milli Eğitim Bakanlığı 2015-2019 Stratejik Planında STEM'in güçlendirilmesine yönelik amaçlara yer vermiştir. TIMSS ve PISA gibi sınavlarda ülkemiz beklenen sonuçlara ulaşamamıştır. Bu sonuçların beklenilen düzeye çıkarılabilmesi için ülkemizde STEM eğitimi öncelik verilmesi gereken önemli bir yaklaşımdır (MEB, 2016). 
Türkiye’de 2013-2014 eğitim-öğretim yılında değişiklikler yapılarak uygulanmaya başlanan yeni müfredatta öğrencinin başarı durumunu anlık performansa dayalı olarak bir değerlendirme ile belirlemek yerine öğrenme süreciyle bütünleşmiş bir değerlendirilmenin tercih edildiği görülmektedir. Ayrıca bu sistem, eğitim sürecinde öğretmenleri ve okulu daha aktif hale getirmeyi, ülke genelinde müfredatın eş zamanlı yürütülmesini, öğretmenin meslekî performansını artırmayı ve okul dışı eğitim kurumlarına duyulan ihtiyacın azaltılmasını amaçlamaktadır (MEB, 2018). Bu amaçlara sahip müfredatta yaratıcılık, kritik düşünebilme, iletişim gibi 21. yy becerilerine yer verilmiş ve müfredatta yer alan bilgilerin gerçek hayatla bağlantılı olmasına önem verilmiştir. Ayrıca bilgi aktarımının gerçekleştirilmesi, yaratıcılı̆̆ın arttırılması, yaşam boyu öğrenme alışkanlıkları ve deneyim kazandırılması gibi becerilerin oluşturulmasına yönelik etkinlikler ve çalışmalar yer almıştır (MEB, 2018). Bu değişikliklerle beraber, hedeflenen kazanımların gerçekleşebilmesi için yeni öğretim yaklaşımlarına ihtiyaç duyulmuştur. STEM yaklaşımının bu hedeflere uygun bir öğretim yöntemi olması STEM'e olan yönelimi arttırmıştır. Bu sebeplerden dolayı 2014 yılından sonra STEM ile ilgili çalışmalarda da artış olduğu görülmektedir (Günbatar ve Bakırcı, 2019).

Ulusal alan yazına bakıldığında STEM eğitiminin Türkiye'deki durumu ile ilgili farklı çalışmaların da yapıldığı görülmektedir. Tezel ve Yaman (2017) ulusal alan yazında STEM konusunda yapılan çalışmaları incelemiş ve çalışmaların sonuçları hakkında bilgi vermiştir. Tezel ve Yaman'ın bu incelemesinde Türkiye'de STEM ile ilgili yapılan çalışmalarda 2014 yılından sonra araştırmaların arttı̆̆ı sonucuna ulaşılmıştır.

Elmalı ve Balkan Kıyıcı (2017) çalışmalarında FeTeMM ile ilgili makale ve lisansüstü tezleri yöntem ve konu eğilimi bakımından incelemişlerdir. Bu doğrultuda 30 makale ve 5 lisansüstü tez çalışması, araştırmanın modeli, çalışma grubu, veri toplama araçları, veri analiz yöntemi ve araştırma konusu içerikleri açısından analiz edilmiştir. Araştırma sonucunda; incelenen çalışmaların kuramsal temelli yapıldığı, deneysel çalışmaların ise genel olarak bir proje ürünü oluşturmaya yönelik olduğu görülmüştür.

Kızılay (2018) Türkiye'de öğretmen eğitimi alanında STEM konusunda yapılan 13 çalışmayı incelemiştir. Araştırma sonucunda; çalışmalarda örneklemi genellikle fen bilgisi öğretmen adaylarının oluşturduğu, incelenen değişkenlerin sıklıkla bilişsel alan özelliklerinin olduğu, STEM disiplinleri arası bağlantının en çok incelenen bileşen olduğu ve genellikle nitel araştırma yaklaşımının benimsendiği tespit edilmiştir.

Daşdemir vd. (2018) Türkiye'de STEM eğitiminin eğilimi ile ilgili çalışmasında lisansüstü tez ve makaleleri betimsel içerik analizi yöntemi ile incelemiştir. Yapılan 
incelemeler sonucunda Türkiye'de akademik çalışmalar arasında makalelerin lisansüstü tezlerden fazla olduğu, STEM eğitimi ile ilgili en çok çalışmanın 2017 yılında yapıldı̆̆g, çalışmaların en çok iki yazarlı olarak yürütüldüğü ve en çok nitel araştırma yönteminin kullanıldığı sonuçlarına ulaşılmıştır. Yapılan çalışmalarda en çok amaçlı örnekleme yönteminin kullanıldığı ve en çok çalışılan grubun ortaokul öğrencileri olduğu tespit edilmiştir. İnceledikleri çalışmalarda veri toplama aracı olarak en çok başarı/bilgi/beceri testlerinin tercih edildiği, veri analizi olarak da en fazla betimsel içerik analizi ve parametrik testlerin kullanılmış olduğu sonuçlarına ulaşılmıştır.

Elmalı ve Balkan Kıyıcı'nın (2017) çalışmasında 30 makale ve 5 lisansüstü tez; Daşdemir vd.’nin (2018) çalışmasında 19 lisansüstü tez ve 32 makale araştırma kapsamına alınmıştır. Tezel ve Yaman'ın (2017) çalışmasında ise nicel bir sayı belirtilmemekle birlikte 2017 yılı öncesindeki çalışmalar araştırma kapsamına alınmıştır. Bu açıdan bakıldığında, yapılan bu çalışma ile ulusal alan yazında 2010-2018 yılları arasında STEM eğitimi ile ilgili yapılmış 52 makale ve 45 lisansüstü tez olmak üzere toplam 97 çalışma araştırma kapsamına alınmıştır. Araştırma kapsamına alınan çalışma sayısının alan yazında bulunan benzeri çalışmalardan daha fazla olması bu çalışmanın diğer çalışmalardan ayrılmasını sağlayacaktır.

Tüm bu çalışmalar dikkate alındığında ülkemizde STEM eğitiminin artan bir öneme sahip olduğu anlaşılmaktadır. Bununla birlikte bu alanda yapılan çalışmalarda incelenen makale ve tez sayılarının sınırlı tutulduğu ve bu alanda daha fazla verinin analiz edilmesine ihtiyaç olduğu düşünülmektedir. Ayrıca STEM alanı sürekli güncellenmesi gereken bir alan olması nedeniyle de, inceleme tarihi daha güncel olan çalışmaların da araştırmalara dahil edilmesi önem taşımaktadır. Bu noktalardan hareketle, bu çalışma ile Türkiye'de STEM eğitimi ile ilgili yapılan lisansüstü tez ve makalelerin bazı değişkenler açısından incelenmesi ve ülkemizde bu alanda yapılmış çalışmaların genel bir durumunun (ya da eğiliminin) ortaya konulması amaçlanmaktadır. Ülkemizde yapılan STEM eğitimi çalışmalarının içeriği hakkında bilgi verilmesi, az çalışılan alanların belirlenmesi ve alan yazında eksik olan noktaların ortaya konması amacıyla gerçekleştirilmiştir. Araştırmadan elde edilen bulgular 1şığında Türkiye'de yapılan çalışmalara bir rehber olması amaçlanmıştır. Çalışma, Türkiye’de 2010-2018 yılları arasında yürütülen, erişime açık yüksek lisans ve doktora tezleri ile ULAKBİM-Dergi Park veri tabanında bulunan dergiler ile sınırlıdır.

Araştırmanın amacı kapsamında aşağıdaki sorulara yanıt aranmıştır: 
1) Ülkemizde 2010-2018 yılları arasında STEM eğitimi ile ilgili yapılan çalışmaların genel durumu nasildir?

a) Ülkemizde 2010-2018 yılları arasında STEM eğitimi ile ilgili yapılan araştırmaların türü ve yıllara göre dağılımı nasıldır?

b) Ülkemizde 2010-2018 yılları arasında STEM eğitimi ile ilgili yapılan tezlerin erişilebilirlik durumları, danışmanlarının akademik unvanları ve tezlerin yürütüldüğü üniversitelerin dağılımları nedir?

c) Ülkemizde 2010-2018 yılları arasında STEM eğitimi ile ilgili yapılan araştırmalarda çalışılan bağımlı değişkenler, kullanılan desen türleri, veri toplama araçları, veri analizi yöntemleri ve çalışılan örneklem grupları nelerdir?

\section{Yöntem}

\section{Araştırmanın Yöntemi}

$\mathrm{Bu}$ çalışmada nitel araştırma yöntemlerinden doküman incelemesi yöntemi kullanılmıştır. Doküman incelemesi, araştırılması hedeflenen olgu veya olgular hakkında bilgi içeren yazılı materyallerin analizini kapsar (Yıldırım ve Şimşek, 2018; s. 189). Günümüzde STEM eğitimi ile ilgili yapılan çalışmaların birçoğuna doküman incelemesi yöntemi ile ulaşmak mümkün olduğundan araştırmada bu yöntem kullanılmıştır.

\section{Verilerin Toplanması}

Bu çalışmada 2010-2018 yılları arasında ulusal alan yazında STEM eğitimi ile ilgili yapılmış makale ve lisansüstü tezler incelenmiştir. Lisansüstü tezlerin taranmasında YÖK Ulusal Tez Merkezi veri tabanında bulunan, 2010-2018 yıllarına ait ve anahtar kelimelerinde "STEM, STEM eğitimi, FeTeMM, entegre STEM öğretimi” terimlerini içeren toplam 45 lisansüstü tez incelenmiştir. Bu kapsamda incelenen tezlerin bazılarının kısıtlanmış olması nedeniyle, araştırma kapsamında istenilen tüm bilgilere ulaşılamamıştır. $\mathrm{Bu}$ yüzden araştırmada tezlerin erişim durumunun incelenmesi gerekliliği de ortaya çıkmıştır. Tezlerin erişilebilirlik durumları Tablo 1'de verilmiştir. 
Tablo 1

Lisansüstü Tezlerin Erişilebilirlik Durumları

\begin{tabular}{lcc}
\hline Erişilebilirlik Durumu & Frekans (f) & Yüzde(\%) \\
\hline Erişilebilir & 28 & 62,2 \\
Kısıtlı & 17 & 37,8 \\
\hline Toplam & $\mathbf{4 5}$ & $\mathbf{1 0 0}$ \\
\hline
\end{tabular}

Tablo 1'de yer alan verilere göre, lisansüstü tezlerin 28 tanesinin erişilebilir, 17 tanesinin kısıtlı durumda olduğu görülmektedir.

Makalelerin seçiminde ise TÜBİTAK ULAKBİM-Dergi Park veri tabanında bulunan eğitimle ilgili 64 dergi listelenmiştir. Listelenen dergiler, 2010 yılından itibaren çıkarılan bask1 sayısı, çıkarılan baskılarda yayınlanan toplam makale sayısı ve STEM'le ilgili yayınlanan makale sayısı bakımından incelenmiştir. Dergilerin 2010 yılından itibaren çıkardığg 1119 adet baskı taranmış, bu baskılarda toplam 13313 adet makalenin yayınlandığ tespit edilmiştir. Yayınlanan makaleler arasından işe koşulan anahtar kelimelerin aranması sonucunda, seçilen dergiler içerisinden 38 tanesinin istenen türde çalışma içerdiği görülmüştür. Dergilerde yayınlanan 13313 makale arasından sadece 54 makalenin aranan anahtar kelimeleri içerdiği tespit edilmiş, 52 makale araştırma kapsamına alınmıştır. Makalelerin en çok yayınlandıkları dergilere göre dağılımları Tablo 2'de verilmiştir. Diğer dergiler kısmında sadece bir tane makale yayınlanan dergiler yer almaktadır.

Tablo 2

STEM Ĕ̆itimi İle İlgili Yapılan Makalelerin Yayınlandı̆̆ı Dergilere Göre Dă̆ılımı

\begin{tabular}{ll}
\hline \multicolumn{1}{c}{ Dergi Adı } & $\begin{array}{c}\text { STEM'le İlgili Yayınlanan } \\
\text { Makale Sayısı }\end{array}$ \\
\hline Sakarya University Journal of Education & 4 \\
\hline Anemon Muş Alparslan Üniversitesi Sosyal Bilimler Dergisi & 3 \\
\hline Journal of STEAM Education & 3 \\
\hline Pegem Eğitim ve Öğretim Dergisi & 3 \\
\hline Atatürk Üniversitesi Kazım Karabekir Eğitim Fakültesi & 2 \\
\hline Dergisi & 2 \\
\hline Bartın Üniversitesi Eğitim Fakültesi Dergisi & 2 \\
\hline Eğitim ve Bilim & 2 \\
\hline Hacettepe Üniversitesi Eğitim Fakültesi Dergisi & 2 \\
\hline Kastamonu Üniversitesi Kastamonu Eğitim Dergisi & 2 \\
\hline
\end{tabular}




\begin{tabular}{lc}
\hline Trakya Eğitim Dergisi & 2 \\
\hline Yüzüncü Yıl Üniversitesi Eğitim Fakültesi Dergisi & 2 \\
\hline Diğer Dergiler & 25 \\
\hline Toplam & $\mathbf{5 4}$ \\
\hline
\end{tabular}

Araştırmaya dahil edilen her bir çalışmanın kodları Tablo 3'te verilmiştir. Araştırmalar yayın yılına göre sıralanarak analizlerde tanımlayıcı olması açısından " $\mathrm{X}_{1}, \mathrm{X}_{2}, \mathrm{X}_{3}, \ldots, \mathrm{X}_{97}$ " olacak şekilde kodlanmıştır.

Tablo 3

Incelenen Çalışmalar ve Kodları

\begin{tabular}{|c|c|c|c|}
\hline Çalışma & Kod & Çalışma & Kod \\
\hline Saçan (2018) & $\mathrm{X}_{1}$ & Alan (2017) & $\mathrm{X}_{50}$ \\
\hline Çiftçi (2018) & $\mathrm{X}_{2}$ & Taştan Akdağ (2017) & $\mathrm{X}_{51}$ \\
\hline Kayalar (2018) & $\mathrm{X}_{3}$ & Sarıcan (2017) & $\mathrm{X}_{52}$ \\
\hline Duygu (2018) & $\mathrm{X}_{4}$ & Hacioğlu (2017) & $\mathrm{X}_{53}$ \\
\hline Aygen (2018) & $\mathrm{X}_{5}$ & Tabaru (2017) & $\mathrm{X}_{54}$ \\
\hline Alıc1 (2018) & $\mathrm{X}_{6}$ & Şatgeldi (2017) & $\mathrm{X}_{55}$ \\
\hline K1lınç (2018) & $\mathrm{X}_{7}$ & Koç (2017) & $\mathrm{X}_{56}$ \\
\hline Biçer (2018) & $\mathrm{X}_{8}$ & Salman Parlakay (2017) & $\mathrm{X}_{57}$ \\
\hline Genek (2018) & $\mathrm{X}_{9}$ & Karakaş (2017) & $\mathrm{X}_{58}$ \\
\hline Bilekyiğit (2018) & $\mathrm{X}_{10}$ & Tantu (2017) & $\mathrm{X}_{59}$ \\
\hline Doğanay (2018) & $\mathrm{X}_{11}$ & Ocak (2017) & $\mathrm{X}_{60}$ \\
\hline Gazibeyoğlu (2018) & $\mathrm{X}_{12}$ & Konca Şentürk (2017) & $\mathrm{X}_{61}$ \\
\hline Öcal (2018) & $\mathrm{X}_{13}$ & Sar1 (2017) & $\mathrm{X}_{62}$ \\
\hline Açıkgöz (2018) & $\mathrm{X}_{14}$ & Özçelik (2017) & $\mathrm{X}_{63}$ \\
\hline Bozan (2018) & $\mathrm{X}_{15}$ & Tezsezen (2017) & $\mathrm{X}_{64}$ \\
\hline Karc1 (2018) & $\mathrm{X}_{16}$ & Gökbayrak (2017) & $\mathrm{X}_{65}$ \\
\hline Dedetürk (2018) & $\mathrm{X}_{17}$ & Karakaya (2017) & $\mathrm{X}_{66}$ \\
\hline Şen (2018) & $\mathrm{X}_{18}$ & Öztürk (2017) & $\mathrm{X}_{67}$ \\
\hline Poyraz (2018) & $\mathrm{X}_{19}$ & Ensari (2017) & $\mathrm{X}_{68}$ \\
\hline Altaş (2018) & $\mathrm{X}_{20}$ & Derin (2017) & $\mathrm{X}_{69}$ \\
\hline Girgin (2018) & $\mathrm{X}_{21}$ & Aydın, Saka ve Guzey (2017) & $\mathrm{X}_{70}$ \\
\hline Uğraş ve Genç (2018) & $\mathrm{X}_{22}$ & Elmalı ve Balkan Kıyıcı (2017) & $\mathrm{X}_{71}$ \\
\hline Güder ve Gürbüz (2018) & $\mathrm{X}_{23}$ & Koyunlu Ünlü ve Dökme (2016) & $\mathrm{X}_{72}$ \\
\hline Yaman, Özdemir ve Akar Vural (2018) & $\mathrm{X}_{24}$ & Çevik, Danıştay ve Yağcı (2017) & $\mathrm{X}_{73}$ \\
\hline Yildırım (2018) & $\mathrm{X}_{25}$ & Yıldırım ve Selvi (2017) & $\mathrm{X}_{74}$ \\
\hline Gülhan ve Şahin (2018) & $\mathrm{X}_{26}$ & $\begin{array}{l}\text { Așık, Doğança Küçük, Helvacı ve Çorlu } \\
\text { (2017) }\end{array}$ & $\mathrm{X}_{75}$ \\
\hline Karakaya, Avgın ve Yılmaz (2018) & $\mathrm{X}_{27}$ & Yildırım, (2017) & $\mathrm{X}_{76}$ \\
\hline Yıldırım ve Selvi (2018) & $\mathrm{X}_{28}$ & $\begin{array}{l}\text { Pekmez, Yılmaz, Alaçam Akşit ve Güler } \\
\text { (2017) }\end{array}$ & $\mathrm{X}_{77}$ \\
\hline Şahin ve Kabasakal (2018) & $\mathrm{X}_{29}$ & Karışan ve Yurdakul (2017) & $\mathrm{X}_{78}$ \\
\hline Bahar, Yener, Yılmaz, Emen ve Gürer (2018) & $\mathrm{X}_{30}$ & Dönmez (2017) & $\mathrm{X}_{79}$ \\
\hline Korkut Owen ve Eraslan Çapan (2018a) & $\mathrm{X}_{31}$ & Gökbayrak ve Karışan (2017) & $\mathrm{X}_{80}$ \\
\hline İnce, Mısır, Küpeli ve Firat (2018) & $\mathrm{X}_{32}$ & $\begin{array}{l}\text { Y1lmaz, Yiğit Koyunkaya, Güler ve Güzey } \\
\text { (2017) }\end{array}$ & $\mathrm{X}_{81}$ \\
\hline Güven, Selvi ve Benzer (2018) & $\mathrm{X}_{33}$ & Gülgün, Yılmaz ve Çağlar (2017) & $\mathrm{X}_{82}$ \\
\hline
\end{tabular}


Seren ve Veli (2018)

Üçüncüoğlu ve Bozkurt Altan (2018)

Gülen ve Yaman (2018)

Timur ve İnançlı (2018)

Bakırcı ve Kutlu (2018)

Tüzün ve Tüysüz (2018)

Yıldırım ve Türk (2018)

Özbilen (2018)

Daşdemir vd. (2018)

Delen ve Uzun (2018)

Korkut Owen ve Eraslan Çapan (2018b)

Deveci (2018)

Arıkan (2018)

Özkan ve Çepni (2018)

M. Tekerek \& B. Tekerek (2018)

Karakaya, Ünal, Çimen ve Yılmaz (2018)

\begin{tabular}{l|ll}
$\mathrm{X}_{34}$ & Kalkan ve Eroğlu (2017) & $\mathrm{X}_{83}$ \\
$\mathrm{X}_{35}$ & Damar, Durmaz ve Önder (2017) & $\mathrm{X}_{84}$ \\
$\mathrm{X}_{36}$ & Çolakoğlu ve Günay Gökben (2017) & $\mathrm{X}_{85}$ \\
$\mathrm{X}_{37}$ & Irkıçatal (2016) & $\mathrm{X}_{86}$ \\
$\mathrm{X}_{38}$ & Yıldırım (2016) & $\mathrm{X}_{87}$ \\
$\mathrm{X}_{39}$ & Gülhan (2016) & $\mathrm{X}_{88}$ \\
$\mathrm{X}_{40}$ & Öner, R. M. Capraro \& M. M. Capraro (2016) & $\mathrm{X}_{89}$ \\
$\mathrm{X}_{41}$ & Öner \& R.M. Capraro (2016) & $\mathrm{X}_{90}$ \\
$\mathrm{X}_{42}$ & Hacıömeroğlu ve Bulut (2016) & $\mathrm{X}_{91}$ \\
$\mathrm{X}_{43}$ & Eroğlu ve Bektaş (2016) & $\mathrm{X}_{92}$ \\
$\mathrm{X}_{44}$ & Hacı̆̆ğlu, Yamak ve Kavak (2016) & $\mathrm{X}_{93}$ \\
$\mathrm{X}_{45}$ & Çorlu, R. M. Capraro \& M. M. Capraro (2014) & $\mathrm{X}_{94}$ \\
$\mathrm{X}_{46}$ & Ceylan (2014) & $\mathrm{X}_{95}$ \\
$\mathrm{X}_{47}$ & Karakuş ve Us (2013). & $\mathrm{X}_{96}$ \\
$\mathrm{X}_{48}$ & Şahin, Erdoğan, Morgan, M.M. Capraro ve R. & $\mathrm{X}_{97}$ \\
$\mathrm{X}_{49}$ & M. Capraro (2012) &
\end{tabular}

\section{Verilerin Analizi}

Çalışmalardan elde edilen veriler, betimsel analiz tekniği kullanılarak analiz edilmiştir. Betimsel analizde amaç elde edilen bulguları düzenleyerek ve yorumlayarak açık bir biçimde sunmaktır. Araştırmanın kavramsal yapısı önceden açık biçimde belirlenerek gerekli analizler yapılmıştır (Yıldırım ve Şimşek, 2018).

Araştırma kapsamına dahil edilen çalışmalar; araştırmaların türü, tezlerin erişilebilirlik durumu, tez danışmanlarının akademik unvanı, tezlerin yürütüldüğü üniversitelerin dağılımı, araştırmaların yıllara göre dağılımı, çalışılan bağımlı değişkenler, kullanılan araştırma modeli, kullanılan veri toplama araçları, çalışılan örneklem grupları ve kullanılan veri analizi yöntemleri yönünden incelenerek analiz edilmiştir.

\section{Geçerlik ve Güvenirlik}

Araştırmada iç güvenirliği (tutarlılığı) sağlamak için elde edilen veriler, araştırmacılar tarafından bağımsız olarak analiz edilmiştir. Daha sonra araştırmacılar bir araya gelerek yapılan analizleri karşılaştırmış, fikir birliğine varılıncaya kadar tartışmalar yapılmış, analizlere ilişkin ifadelerde tutarlılık sağlanmış ve analizler son halini almıştır. Araştırma bulgularının inandırıcılığını (iç geçerliğini) arttırmak için, incelenen araştırmalarda ulaşılan bulgular herhangi bir yorum katılmadan kullanılmış ve olduğu gibi betimlenmiştir. Araştırmanın iç geçerliğini sağlamak amacıyla elde edilen bulguların kavramsal çerçeveyle uyumlu ve tutarlı olmasına dikkat edilmiştir. Araştırmanın dış geçerliğini sağlamak amacıyla, araştırmanın yöntem ve aşamaları ayrıntılı ve açık bir şekilde anlatılmıştır. Verilerin toplanma 
ve analiz süreçlerinin nasıl yapıldığı verilerin toplanması kısmında detaylı bir şekilde açıklanmıştır.

\section{Bulgular}

Bu çalışma kapsamında incelenen akademik çalışmalara ilişkin betimsel bilgiler Tablo 4’te verilmiştir.

Tablo 4 STEM Ĕ̆itimi Çalışma Türüne Ait Betimsel Bilgiler

\begin{tabular}{lcc}
\hline Çalışma Türü & Frekans (f) & Yüzde (\%) \\
\hline Yüksek Lisans Tezi & 39 & 40,2 \\
Doktora Tezi & 6 & 6,1 \\
Makale & 52 & 53,6 \\
\hline Toplam & $\mathbf{9 7}$ & $\mathbf{1 0 0}$ \\
\hline
\end{tabular}

Tablo 4'te yer alan verilere göre, bu araştırma kapsamında Türkiye'de STEM eğitimi ile ilgili 2010-2018 yılları arasında 39 yüksek lisans tezi, 52 makale ve altı doktora tezi olmak üzere toplam 97 akademik çalışma yapılmıştır. Çalışmaların yıllara göre dağılımı Tablo 5'te verilmiştir.

Tablo 5

STEM Ĕ̆itimi İle İlgili Çalışmaların Yıllara Göre Dă̆ılımı

\begin{tabular}{lcccccccccc}
\hline Araştırma Türü & $\mathbf{2 0 1 0}$ & $\mathbf{2 0 1 1}$ & $\mathbf{2 0 1 2}$ & $\mathbf{2 0 1 3}$ & $\mathbf{2 0 1 4}$ & $\mathbf{2 0 1 5}$ & $\mathbf{2 0 1 6}$ & $\mathbf{2 0 1 7}$ & $\mathbf{2 0 1 8}$ & Toplam \\
\hline Doktora tezi & - & - & - & - & - & - & 2 & 3 & 1 & $\mathbf{6}$ \\
Yüksek lisans tezi & - & - & - & - & 1 & - & 1 & 17 & 20 & $\mathbf{3 9}$ \\
Makale & - & - & 1 & 1 & 1 & - & 6 & 15 & 28 & 52 \\
\hline Toplam & $\mathbf{0}$ & $\mathbf{0}$ & $\mathbf{1}$ & $\mathbf{1}$ & $\mathbf{2}$ & $\mathbf{0}$ & $\mathbf{9}$ & $\mathbf{3 5}$ & $\mathbf{4 9}$ & $\mathbf{9 7}$ \\
\hline
\end{tabular}

Tablo 5'te yer alan verilere göre, tezlerin 21 tanesi 2018 yılında, 20 tanesi 2017 yılında, üç tanesi 2016 yılında ve bir tanesi 2014 yılında hazırlanmıştır. 2014 yılı öncesinde STEM eğitimi ile ilgili hazırlanmış tez bulunmamakta, 2014-2016 yılları arasında hazırlanan lisansüstü tez sayısının da sadece iki adet olduğu görülmektedir. Makalelerin bir tanesi 2012 y1lına, bir tanesi 2013 yılına, bir tanesi 2014 y1lına, altı tanesi 2016 y1lına, 15 tanesi 2017 yılına, 28 tanesi ise 2018 yılına aittir. Yıllara göre STEM alanlarında çıkarılan makale sayısında artış gözlenmektedir. İncelenen tezlerin danışmanlarının akademik unvana göre dağglımı Tablo 6’da verilmiştir. 
Tablo 6

STEM Ĕ̆itimi ile İlgili Tezlerin Danışmanlarının Akademik Unvana Göre Dă̆ılımı

\begin{tabular}{lccc}
\hline Akademik Unvan & Yüksek Lisans Tezi & Doktora Tezi & Toplam \\
\hline Dr. Öğr. Üyesi & 14 & - & 14 \\
Doçent & 16 & - & 16 \\
Profesör & 11 & 5 & 16 \\
\hline Toplam & $\mathbf{4 1}$ & $\mathbf{5}$ & $\mathbf{4 6}$ \\
\hline
\end{tabular}

Tablo 6'da yer alan verilere göre, STEM ile ilgili tezleri yürüten danışmanların 16'sının akademik unvanı doçent, 14'ünün doktor öğretim üyesi, 11'inin ise profesör olduğu görülmektedir. Bu durum STEM ile ilgili yürütülen yüksek lisans tezlerinde danışman unvanı açısından bir farklılığın olmadığını göstermektedir. Bir tezde iki eş danışman olması nedeniyle, 45 adet lisansüstü tez 46 danışman tarafından yürütülmüştür. Ayrıca doktora tezlerini sadece profesör unvanına sahip akademik danışmanların yürüttüğü görülmektedir. İncelenen tezlerin yürütüldüğü üniversitelere göre dağılımı Tablo 7’de verilmiştir.

Tablo 7

Tezlerin Yürütüldüğ̈̈ Üniversitelere Göre Dă̆glımı

\begin{tabular}{|c|c|c|c|c|c|c|c|c|c|c|c|}
\hline \multirow{2}{*}{$\begin{array}{c}\text { Araştırmanın } \\
\text { Yürütüldüğ̈̈ } \\
\text { Üniversite }\end{array}$} & \multicolumn{5}{|c|}{ Yüksek Lisans Tezleri } & \multicolumn{5}{|c|}{ Doktora Tezleri } & \multirow[t]{2}{*}{ Toplam } \\
\hline & 2014 & 2015 & 2016 & 2017 & 2018 & 2014 & 2015 & 2016 & 2017 & 2018 & \\
\hline Kastamonu Ü. & & & & & 3 & & & & & & 3 \\
\hline ODTÜ & & & & 2 & 1 & & & & & & 3 \\
\hline Kırıkkale Ü. & & & & & 2 & & & & & & 2 \\
\hline Firat Ü. & & & & 1 & 1 & & & & & & 2 \\
\hline İstanbul Aydın Ü. & & & & 2 & & & & & & & 2 \\
\hline Van Yüzüncü Yıl & & & & 2 & & & & & & & 2 \\
\hline Marmara Ü. & & & & 1 & & & & 1 & & & 2 \\
\hline $\begin{array}{l}\text { Eskişehir } \\
\text { Osmangazi Ü. }\end{array}$ & & & & & 1 & & & & & & 2 \\
\hline Yıldız Teknik Ü. & & & & & 2 & & & & & & 2 \\
\hline Gazi Üniversitesi & & & & & & & & 1 & 1 & & 2 \\
\hline $\begin{array}{l}\text { Karamanoğlu } \\
\text { Mehmetbey Ü. }\end{array}$ & & & & & 1 & & & & & & 1 \\
\hline $\begin{array}{l}\text { Kahramanmaraş } \\
\text { Sütçü İmam Ü. }\end{array}$ & & & & 1 & & & & & & & 1 \\
\hline $\begin{array}{l}\text { Recep Tayyip } \\
\text { Erdoğan Ü. }\end{array}$ & & & & & 1 & & & & & & 1 \\
\hline Dokuz Eylül Ü. & & & & & 1 & & & & & & 1 \\
\hline Ondokuz Mayıs & & & & & & & & & 1 & & 1 \\
\hline Giresun Ü. & & & & & 1 & & & & & & 1 \\
\hline Çukurova Ü. & & & & & 1 & & & & & & 1 \\
\hline Erciyes Ü. & & & & & 1 & & & & & & 1 \\
\hline Çanakkale & & & & & 1 & & & & & & 1 \\
\hline
\end{tabular}


Onsekiz Mart Ü.

Anadolu Ü.

Muş Alparslan Ü.

Niğde Ömer

Halisdemir Ü.

Akdeniz Ü.

İstanbul Gelişim

Mustafa Kemal

Pamukkale Ü.

Yeditepe Ü.

Muğla Sitk1

Koçman Ü.

Kafkas Ü.

Ege Ü.

Hacettepe Ü.

Bahçeşehir Ü.

Uludağ Ü.

Boğaziçi Ü.

Toplam

ISSN: 1305-2020 


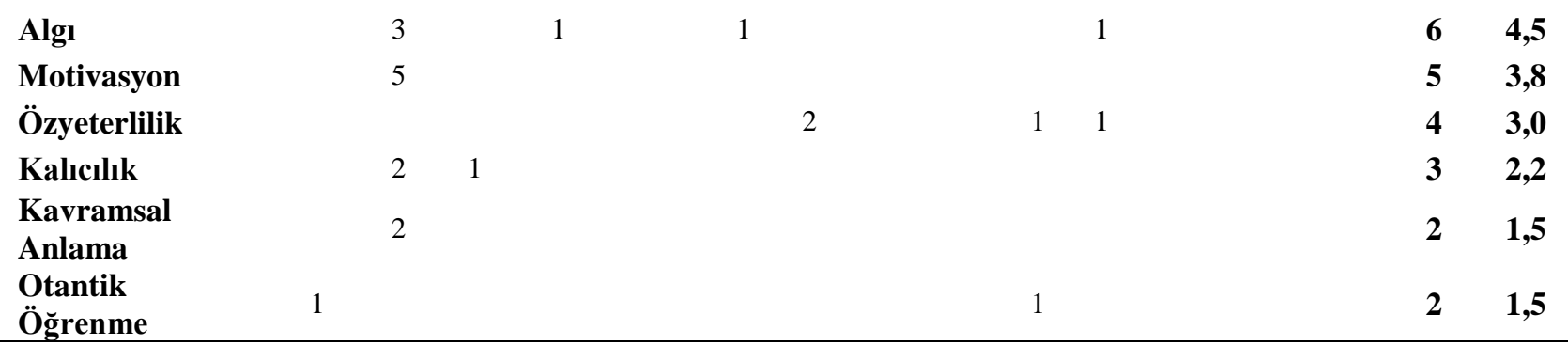

Tablo 8'de yer alan verilere göre, en çok çalışılan bağımlı değişkenin beceri (\%22,9) olduğu görülmektedir. Bu değişkenin çalışıldığı örneklem grupları incelendiğinde ise, en fazla çalışılan grubun ortaokul öğrencileri olduğu ve onu fen bilimleri öğretmen adaylarının izlediği gözlemlenmiştir. Becerilerle ilgili yapılan çalışmalarda en çok Bilimsel Süreç Becerileri değişken olarak kullanılmıştır. Araştırmalarda en fazla çalışılan ikinci bağımlı değişkenin ise tutum $(\% 19,0)$ olduğu görülmektedir. Bu değişkenin en çok çalışıldığı grup ise ortaokul öğrencileridir.

Tabloda verilen değişkenler dışında çevre sorunlarına duyarlılık, doğaya bağlılık, çevreye karşı davranış ve sistem düşünme zekâsı, fen bilimleri öğretmen adayları ile çalışılan diğer değişkenlerdir. Ayrıca ortaokul öğrencileriyle STEM disiplinlerini anlamaya yönelik, lise öğrencileriyle de Müspet ve Doğal Bilimleri tercih etme durumlarına yönelik çalışmalar yapılmıştır.

Araştırma kapsamında ele alınan çalışmalarda kullanılan yöntemler; nicel, nitel ve karma olarak sınıflandırılarak incelenmiştir. $\mathrm{Bu}$ sınıfa dahil olmayan ya da yöntem bilgisi verilmeyen araştırmalar da belirtilmemiş olarak sınıflandırılmıştır. Bu değişkene ilişkin bulgular Tablo 9’da verilmiştir.

Tablo 9

Incelenen Araştırmalarda Kullanılan Yöntemler

\begin{tabular}{llcc}
\hline \multirow{2}{*}{ Araştırma Modeli } & & $\begin{array}{c}\text { Frekans } \\
\text { (f) }\end{array}$ & $\begin{array}{c}\text { Yüzde } \\
\text { (\%) }\end{array}$ \\
\cline { 2 - 5 } Nicel & Deneysel desen & 19 & 19,58 \\
& Tarama Modeli & 16 & 16,49 \\
& Geçerlik- güvenirlik çalışması & 4 & 4,12 \\
\cline { 2 - 5 } Nitel & Toplam & $\mathbf{3 9}$ & $\mathbf{4 0 , 2 0}$ \\
\hline \multirow{3}{*}{} & Durum Çalışması & 19 & 19,58 \\
& Doküman İncelemesi & 5 & 5,15 \\
& Fenomenoloji & 3 & 3,09 \\
& Temel nitel araştırma & 3 & 3,09 \\
\hline
\end{tabular}




\begin{tabular}{llcc}
\cline { 2 - 4 } & Eylem araştırması & 2 & 2,06 \\
& Teorik çalışma & 2 & 2,06 \\
\cline { 2 - 4 } & Toplam & $\mathbf{3 4}$ & $\mathbf{3 5 , 0 5}$ \\
\hline Karma & & $\mathbf{2 1}$ & $\mathbf{2 1 , 6 4}$ \\
Belirtilmemiş & & $\mathbf{3}$ & 3,09 \\
\hline Toplam & & $\mathbf{9 7}$ & $\mathbf{1 0 0}$ \\
\hline
\end{tabular}

Tablo 9’a göre, incelenen araştırmalarda en fazla nicel araştırma yönteminin tercih edildiği görülmektedir. Nicel araştırma yöntemleri içinde de deneysel yöntem ile tarama modellerinin sıklıkla kullanıldığg bulgusuna ulaşılmıştır. Nicel araştırma modeli ile yürütülen 39 çalışmanın 19 tanesinde deneysel desen kullanılmıştır. Nitel araştırma yöntemleri içinde ise durum çalışmasının en fazla tercih edilen yöntem olduğu dikkati çekmektedir. Çalışmalarda kullanılan veri toplama araçlarına ilişskin istatistikler Tablo 10'da verilmiştir.

Tablo 10

Incelenen Araştırmalarda Kullanılan Veri Toplama Araçları

\begin{tabular}{lcc}
\hline Veri Toplama Araçları & Frekans (f) & Yüzde (\%) \\
\hline Ölçekler & 74 & 35,0 \\
Testler & 40 & 18,9 \\
Diğerleri & 97 & 45,9 \\
\hline
\end{tabular}

Tablo 10'da yer alan verilere göre, incelenen araştırmalarda en çok kullanılan veri toplama aracının ölçekler olduğu görülmektedir Araştırmalarda 49 tanesi tezlerde, 25 tanesi makalelerde olmak üzere toplam 74 ölçek kullanılmıştır. Tezlerde kullanılan ölçek özellikleri incelendiğinde; dört tanesinin araştırmacılar tarafından geliştirildiği, üç tanesinin Türkçeye uyarlama çalışmasının yapıldığı ve kullanılan 11 ölçeğin de daha önce Türkçeye uyarlanmış ölçekler olduğu görülmüştür. Geriye kalan ölçeklerin durumu ile ilgili ayrıntılı bilgiye ulaşılamamıştır. Makalelerde kullanılan ölçeklere bakıldığında ise; daha önce uyarlaması yapılan 15 ölçeğin kullanıldı̆̆ı, sekiz tane ölçeğin araştırmacılar tarafindan geliştirildiği, iki tanesinin ise Türkçeye uyarlama çalışmasının yapıldığı tespit edilmiştir. Ölçekler içerisinde en çok tutum ölçeklerinin ( $\mathrm{n}=19)$ kullanıldı̆̆ dikkati çekmektedir.

Veri toplama araçlarından bir diğeri olan testlere bakıldığında, çalışmalarda 13 farklı testin kullanıldığı, bunlardan en çok akademik başarı testlerinin $(n=14)$ tercih edildiği görülmüştür. Diğer ölçme araçları kısmında ise 45 farklı ölçme aracı kullanılmıştır. Bunların arasında en çok yarı yapılandırılmış görüşme formları $(n=28)$ ve gözlem formlarının $(n=8)$ kullanıldı̆̆ı bulunmuştur. İncelenen araştırmalarda toplamda 87 farklı veri toplama aracı 
kullanılmıştır. Ayrıca dört çalışmanın veri toplama araçlarına dair herhangi bir bilgiye ulaşılamamıştır. Araştırmalarda çalışılan örneklem gruplarına ilişkin istatistikler Tablo 11'de verilmiştir.

\section{Tablo 11}

Incelenen Araştırmalarda Çalışılan Örneklem Grupları

\begin{tabular}{|c|c|c|c|c|}
\hline Örneklem Grubu & & Çalışma Kodu & $\begin{array}{c}\text { Frekans } \\
\text { (f) }\end{array}$ & $\begin{array}{c}\text { Yüzde } \\
(\%)\end{array}$ \\
\hline \multirow{10}{*}{ Öğretmenler } & Fen Bilimleri Öğretmeni & $\begin{array}{c}\mathrm{X}_{8}, \mathrm{X}_{17}, \mathrm{X}_{23}, \mathrm{X}_{37}, \mathrm{X}_{38}, \mathrm{X}_{41}, \mathrm{X}_{49}, \mathrm{X}_{55} \\
\mathrm{X}_{58}, \mathrm{X}_{59}, \mathrm{X}_{73}, \mathrm{X}_{82}, \mathrm{X}_{92}, \mathrm{X}_{93}\end{array}$ & 14 & 11,5 \\
\hline & Sınıf Öğretmeni & $\mathrm{X}_{15}, \mathrm{X}_{21}, \mathrm{X}_{67}, \mathrm{X}_{96}$ & 4 & 3,2 \\
\hline & Matematik Öğretmeni & $\mathrm{X}_{23}, \mathrm{X}_{41}, \mathrm{X}_{73}, \mathrm{X}_{93}$ & 4 & 3,2 \\
\hline & Fizik Öğretmeni & $\mathrm{X}_{55}, \mathrm{X}_{59,} \mathrm{X}_{93}$ & 3 & 2,5 \\
\hline & Kimya Öğretmeni & $\mathrm{X}_{55}, \mathrm{X}_{93}$ & 2 & 1,6 \\
\hline & Bilişim Teknolojileri Öğretmeni & $\mathrm{X}_{59}, \mathrm{X}_{73}$ & 2 & 1,6 \\
\hline & Biyoloji Öğretmeni & $\mathrm{X}_{55}$ & 1 & 0,8 \\
\hline & Okul Öncesi Öğretmeni & $\mathrm{X}_{14}$ & 1 & 0,8 \\
\hline & Özel Öğretim Öğretmeni & $\mathrm{X}_{39}$ & 1 & 0,8 \\
\hline & Toplam & & 32 & 26,2 \\
\hline \multirow{7}{*}{$\begin{array}{l}\text { Öğretmen } \\
\text { Adayları }\end{array}$} & Fen Bilimleri Öğretmen Adayları & $\begin{array}{c}\mathrm{X}_{3}, \mathrm{X}_{4}, \mathrm{X}_{5}, \mathrm{X}_{35}, \mathrm{X}_{37}, \mathrm{X}_{45}, \mathrm{X}_{50}, \mathrm{X}_{53}, \\
\mathrm{X}_{64}, \mathrm{X}_{65}, \mathrm{X}_{76}, \mathrm{X}_{80}\end{array}$ & 12 & 9,8 \\
\hline & $\begin{array}{l}\text { Eğitim Fakültesinde Öğrenim } \\
\text { Gören Öğretmen Adayları }\end{array}$ & $\mathrm{X}_{7}, \mathrm{X}_{18}, \mathrm{X}_{24}, \mathrm{X}_{25}, \mathrm{X}_{48}, \mathrm{X}_{69}$ & 6 & 4,9 \\
\hline & Sınıf Öğretmeni Adayları & $\mathrm{X}_{20}, \mathrm{X}_{40}, \mathrm{X}_{91}$ & 3 & 2,5 \\
\hline & Fizik Öğretmeni Adayı & $\mathrm{X}_{68}$ & 1 & 0,8 \\
\hline & Matematik Öğretmeni Adayı & $\mathrm{X}_{43}$ & 1 & 0,8 \\
\hline & Okul öncesi öğretmen adayı & $\mathrm{X}_{22}$ & 1 & 0.8 \\
\hline & Toplam & & 24 & 19,6 \\
\hline \multirow{7}{*}{ Öğrenciler } & Okul öncesi öğrencileri & $\mathrm{X}_{13}$ & 1 & 0,8 \\
\hline & İlkokul öğrencileri & $\mathrm{X}_{9}, \mathrm{X}_{15}, \mathrm{X}_{21}, \mathrm{X}_{54}, \mathrm{X}_{67}, \mathrm{X}_{70}, \mathrm{X}_{77}, \mathrm{X}_{96}$ & 8 & 6,6 \\
\hline & Ortaokul öğrencileri & $\begin{array}{c}\mathrm{X}_{1}, \mathrm{X}_{2}, \mathrm{X}_{6}, \mathrm{X}_{11}, \mathrm{X}_{12}, \mathrm{X}_{16}, \mathrm{X}_{17}, \mathrm{X}_{23}, \mathrm{X}_{26} \\
\mathrm{X}_{27}, \mathrm{X}_{28}, \mathrm{X}_{32}, \mathrm{X}_{33}, \mathrm{X}_{36}, \mathrm{X}_{51}, \mathrm{X}_{52}, \mathrm{X}_{56} \\
\mathrm{X}_{57,} \mathrm{X}_{58}, \mathrm{X}_{61}, \mathrm{X}_{66}, \mathrm{X}_{70}, \mathrm{X}_{74}, \mathrm{X}_{77}, \mathrm{X}_{78} \\
\mathrm{X}_{79}, \mathrm{X}_{81}, \mathrm{X}_{84}, \mathrm{X}_{86}, \mathrm{X}_{87}, \mathrm{X}_{88}, \mathrm{X}_{95}\end{array}$ & 32 & 26,2 \\
\hline & Lise öğrencileri & $\mathrm{X}_{10}, \mathrm{X}_{31}, \mathrm{X}_{44}, \mathrm{X}_{60}, \mathrm{X}_{79}, \mathrm{X}_{89}, \mathrm{X}_{90}, \mathrm{X}_{97}$ & 8 & 6,6 \\
\hline & Üstün Yetenekli Öğrenciler & $\mathrm{X}_{29}, \mathrm{X}_{63}, \mathrm{X}_{72}, \mathrm{X}_{83}$ & 4 & 3,2 \\
\hline & Mühendislik Lisans Öğrencileri & $\mathrm{x}_{62}$ & 1 & 0,8 \\
\hline & Toplam & & 54 & 44,2 \\
\hline & $\mathrm{X}_{19}, \mathrm{X}_{42}, \mathrm{X}_{69}, \mathrm{X}_{79}$ & 4 & 3,2 \\
\hline \multicolumn{2}{|l|}{ Ulaşılamayan } & $\mathrm{X}_{34}, \mathrm{X}_{46}, \mathrm{X}_{47}, \mathrm{X}_{75}$ & 4 & 3,2 \\
\hline \multicolumn{2}{|c|}{ Örneklem Kullanılmamış } & $\mathrm{X}_{30}, \mathrm{X}_{42}, \mathrm{X}_{71}, \mathrm{X}_{94}$ & 4 & 3,2 \\
\hline
\end{tabular}

Tablo 11'de yer alan verilere göre, incelenen araştırmalarda örneklem grubu olarak en çok öğrencilerle çalışıldığı görülmüştür $(\% 44,2)$. Öğrencilerle yürütülen bu çalışmalarda çoğunlukla ortaokul öğrencileri ile çalışıldığı, en az ise okul öncesi dönem çocukları ile 
çalışıldığı dikkati çekmektedir. Araştırmalarda en çok çalışılan ikinci örneklem grubu ise öğretmenlerdir (\%26,2). STEM ile ilgili yürütülen çalışmalarda alanlarının doğası gereği en fazla çalışmanın fen bilimleri öğretmenleri ile yürütüldüğü tespit edilmiştir. Bunun dışında diğer kategorisinde ele alınan örneklem grubunda Fen-Edebiyat Fakültesi mezunu kişiler, fen teknoloji, mühendislik, matematik ve uzaktan eğitim gibi farklı alanlarda uzmanlıkları olan kişiler, takım koçu ve Eğitim Fakültesi dekanları yer almaktadır.

İncelenen makalelerin iki tanesinde MEB öğretim programları karşılaştırıldığı ve iki tanesinde de alan yazın taraması yapıldığı için örneklem tanımlanmamıştır. Çalışmalarda kullanılan veri analizi yöntemlerine ilişkin istatistikler Tablo 12'de verilmiştir.

\section{Tablo 12}

\section{Incelenen Araştırmalarda Kullanılan Veri Analizi Yöntemleri}

\begin{tabular}{lcc}
\hline Veri Analizi Yöntemleri & Frekans (f) & Yüzde (\%) \\
\hline Parametrik Testler & 45 & 29,2 \\
İçerik Analizi & 38 & 24,7 \\
Nonparametrik Testler & 27 & 17,5 \\
Betimsel Analiz & 17 & 11,0 \\
Faktör Analizi & 8 & 5,2 \\
Doküman Analizi & 1 & 0,7 \\
Endüktif Analiz & 1 & 0,7 \\
Belirtilmemiş & 8 & 5,2 \\
Kısıtlı & 9 & 5,8 \\
\hline
\end{tabular}

Tablo 12'de yer alan verilere göre, incelenen araştırmalarda veri analizinde en çok parametrik testlerin kullanıldığı görülmüştür. Parametrik testler arasında en fazla kullanılan test, $\mathrm{t}$ testidir ( $\mathrm{n}=27)$. Veri analizinde en çok kullanılan ikinci yöntem ise içerik analizidir $(\mathrm{n}=38)$. İncelenen çalışmaların sekizinde veri analiz yöntemi belirtilmemişken, dokuz çalışma henüz erişime açık olmadığı için bu kısımdaki istatistiki bilgiler eklenememiştir.

\section{Sonuç ve Tartışma}

Bu çalışmada 2010-2018 yılları arasında ulusal alan yazında STEM eğitimi ile ilgili hazırlanmış olan makale ve lisansüstü tezler bazı değişkenler açısından incelenmiş ve elde edilen bulgular ışığında Türkiye'de STEM eğitimi ile ilgili yürütülecek çalışmalara bir rehber olması amaçlanmıştır.

Günümüzde STEM alanlarına olan ilginin artması ile birlikte, eğitimde STEM yaklaşımının da önemi ortaya çıkmıştır. Bu nedenle STEM'i doğru anlamak ve uygun eğitim- 
öğretim ortamlarına entegre etmek oldukça önemlidir. $\mathrm{Bu}$ durumlar göz önünde bulundurulduğunda bu alanda yapılan çalışmaların STEM yaklaşımına ilişkin bir yol gösterici olacağı söylenebilir. STEM uygulamalarının doğru bir şekilde gerçekleştirilmesi ve hedeflenen kazanımlara ulaşılması bakımından bu alanda yapılan çalışmalar önem kazanmaktadır.

STEM ile ilgili yapılan çalışmaların yıllara göre dağılımlarının incelenmesi sonucunda, ülkemizde 2010 yılından itibaren STEM eğitimi ile ilgili en çok çalışmanın 2018 yılında yapıldığg tespit edilmiştir. Türkiye'de STEM alanına ait 2014 yılı öncesinde yapılmış herhangi bir lisansüstü tez bulunamamıştır. Bu durumun 2014 yılında Fen Bilimleri öğretim programına dahil edilen Mühendislik Uygulamaları ve program içeriğinde STEM alanları ile ilgili yapılan değişiklikler nedeniyle ortaya çıktığı söylenebilir. Ayrıca TÜSİAD (2014) tarafından hazırlanan rapor ve 2015-2019 Stratejik Planında STEM'in güçlendirilmesine yönelik amaçlardan bahsedilmesi de bu alana ilgiyi arttırmış ve STEM ile ilgili çalışmaların yapılmasına yönelik ihtiyacı ortaya çıkarmıştır. Bu sebeplerden dolayı 2014 yılından sonra alan yazında STEM eğitimi ile ilgili yapılan araştırmalarda artış olduğu söylenebilir. Benzer şekilde, Herdem ve Ünal (2018) ile Çevik (2017)'in yürüttüğü çalışmalarda da özellikle 2014 yılından sonra Türkiye'de STEM eğitimi ile ilgili çalışmaların arttığı sonucuna ulaşılmıştır.

Araştırma kapsamında ele alınan çalışmalar kullanılan araştırma yöntemleri açısından incelendiğinde, en fazla nicel araştırma yöntemlerinin kullanıldığı sonucuna ulaşılmıştır. Nicel araştırmalar içerisinde deneysel yöntemlerin daha fazla tercih edildiği bulunmuştur. Nitel araştırma yöntemleri içerisinde de durum çalışmasının daha çok kullanıldığı sonucuna ulaşılmıştır. STEM eğitiminin tutum, bilimsel süreç becerileri, başarı gibi değişkenlere olan etkisini incelemek amacıyla birçok çalışmanın nicel araştırma yöntemi kullanılarak yürütüldüğü görülmüştür. Nitel araştırma yöntemi, araştırma sürecinin daha iyi gözlenebileceği, daha detaylı ve derinlemesine bilgiler edinilen çalışmaların yapılmasına olanak verebilmektedir. Bu duruma rağmen uygulayıcılara çeşitli kolaylıklar sağlaması ve daha objektif sonuçlara ulaşılmasını sağlaması nedeniyle nicel araştırma yönteminin daha çok kullanıldığı düşünülmektedir. İlgili alan yazında Herdem ve Ünal (2018) nicel yöntemlerin daha fazla kullanıldığını; Daşdemir vd. (2018) nicel yöntemler içerisinde deneme modellerinin, nitel araştırma yöntemleri içerisinde ise durum çalışmasının daha fazla kullanıldığını ifade etmiş olup bu çalışma ile benzer sonuçlar gösterdiği görülmektedir. Tabar (2018); Elmalı ve Balkan Kıyıcı (2017); Çevik (2017); Kızılay (2017) tarafından yapılan çalışmalarda en çok nitel araştırma yönteminin kullanıldığı sonucuna ulaşılmış ve sonuçlar bu 
çalışma ile farklılık göstermektedir. Ancak bahsi geçen bu çalışmalarda ele alınan araştırma sayısı daha sinırlidir.

Araştırmalarda kullanılan veri analizi yöntemleri içerisinde en fazla parametrik testlerin kullanıldı̆̆ tespit edilmiştir. Parametrik testler arasında da en çok kullanılan test ttestidir. Araştırmalarda nicel araştırma yönteminin çok kullanılması ile kullanılan veri analizi yönteminin de t-testi olması paralellik göstermektedir. İlgili alan yazında Daşdemir vd. (2018) en çok betimsel içerik analizi ve parametrik testlerin kullanıldığını; Kızılay (2017) betimsel içerik analizinin kullanıldığını; Çevik (2017) ise tanımlayıcı analiz ve içerik analizinin en çok kullanılan veri analiz yöntemi olduğunu tespit etmiştir.

$\mathrm{Bu}$ çalışma ile incelenen araştırmalarda örneklem grubu olarak en çok ortaokul öğrencileri ile en az ise okul öncesi dönem çocukları ile çalışıldı̆̆ durumun ortaokul fen bilimleri dersi öğretim programında yer alan ünite ve konu alanlarının, STEM yaklaşımı kullanılarak yürütülmesinin daha elverişli olması ile bağlantılı olduğu düşünülmektedir. Araştırmalarda en çok çalışılan ikinci örneklem grubunun öğretmenler olduğu, STEM ile ilgili yürütülen çalışmalarda alanlarının doğası gereği en fazla çalışmanın fen bilimleri öğretmenleri ile yürütüldüğü tespit edilmiştir. Herdem ve Ünal (2018) ile Daşdemir vd. (2018) çalışmasında benzer sonuçlara ulaşarak örneklem grubu olarak en çok ortaokul öğrencilerinin seçildiğini tespit etmiştir. Çevik (2017) ve Tabar (2018) tarafından yapılan çalışmalarda ise örneklem olarak en çok öğretmen adayları ile çalışıldığ 1 ve bunu ortaokul öğrencilerinin takip ettiği sonucuna ulaşılmıştır. Ayrıca Çevik (2017) çalışmasında erken çocukluk dönemindeki çocukların örneklem olarak neredeyse hiç kullanılmadığına değinerek bu araştırmanın sonuçları ile benzer sonuca ulaşmıştır.

İncelenen çalışmalarda veri toplama aracı olarak en fazla ölçekler kullanılmıştır. Çalışmalarda çoğunlukla öğrencilerin STEM alanlarına ve STEM uygulamaları sonucu fene yönelik tutumlarının incelendiği görülmüş, bu nedenle tutum ölçeklerinin diğer ölçeklere oranla daha fazla kullanıldığı sonucuna ulaşılmıştır. Sık kullanılan bir diğer ölçme aracı ise testlerdir. Testler içerisinde akademik başarı testlerinin daha sıklıkla kullanıldığı sonucu ortaya çıkmıştır. İlgili alan yazın çalışmalarına bakıldığında Daşdemir vd.'nin (2018) çalışmasında en fazla başarı/bilgi/beceri testlerinin ve görüşme formunun kullanıldığg; Kızılay'ın (2017) ve Çevik’in (2017) çalışmalarında ise en çok görüşme formunun kullanıldığı sonucuna ulaşılmıştır.

$\mathrm{Bu}$ çalışma ile incelenen araştırmalarda çalışılan bağımlı değişkenler tespit edilmiş, en fazla çalışılan değişkenlerin beceri, tutum, başarı, mesleki ilgi/kariyer tercih ve farkındalık 
olduğu sonucuna ulaşılmıştır. İlgili alan yazında Herdem ve Ünal (2018) akademik başarı, tutum, bilimsel süreç becerileri ve meslek seçimleri üzerine çalışmaların çoğunlukta olduğunu; Elmalı ve Balkan Kıyıcı (2017) tutum, motivasyon, ilgi gibi duyuşsal boyutları içeren çalışmaların daha fazla olduğunu; Tabar (2018) ise alg1, görüş ve tutum değişkenlerinin daha fazla incelendiği sonuçlarına ulaşmıştır. Ayrıca Tabar'ın (2018) çalışmasında mesleki ilgi, bilimsel süreç becerileri ve başarının az çalışılan değişkenler arasında yer aldığı belirtilmiştir.

Tüm bu sonuçlar göz önüne alındığında, fen, mühendislik, matematik ve teknoloji alanlarını entegre bir şekilde ele almayı ve disiplinler arası bir yaklaşım sunmayı amaçlayan STEM eğitimi ile ilgili çalışmaların Türkiye'de sayısının artması önemlidir. Çalışmalarda kullanılan yöntem ve tekniklerdeki farklılaşma ile birlikte, alanda var olan sorunların çözümüne yönelik öneriler geliştirileceği ve özellikle STEM eğitiminin sınıf içi uygulamalarında model oluşturabilecek örneklerin sunulabileceği düşünülmektedir. $\mathrm{Bu}$ nedenle STEM eğitimi ile ilgili ulusal ölçekte yürütülen çalışmaların sistematik analizinin belirli periyotlarla yürütülmesinin, hem bu alanda çalışma yapacak araştırmacılara rehberlik etmesi hem de Türkiye’de var olan durumu bilimsel verilerle ortaya koyması önemlidir.

\section{Öneriler}

$\mathrm{Bu}$ çalışmadan elde edilen sonuçlar doğrultusunda aşağıdaki öneriler sunulabilir:

1. Öğrencilerle yürütülen çalışmalarda en fazla ortaokul öğrencileriyle çalışılmıştır, diğer öğrenci grupları ile de çalışmaların yapılması,

2. Öğretmen ve öğretmen adayları ile yapılan çalışmalarda da en çok fen bilimleri öğretmenleri ve fen bilimleri öğretmen adayları ile çalışılmıştır, diğer alanlardaki öğretmenler ve öğretmen adayları ile yapılan çalışmaların artırılması,

3. Araştırma dergilerinde STEM eğitimine yönelik daha fazla çalışmaya yer verilmesi, dergilerin bu konuda yazarları teşvik etmesi,

4. STEM eğitimine yönelik daha detaylı ve derinlemesine çalışmalar yapılması, bunun için STEM eğitimi sürecinin daha iyi gözlenebileceği nitel çalışmaların artırılması önerilebilir. 


\section{Makalenin Bilimdeki Konumu}

Matematik ve Fen Bilimleri Eğitimi / Fen Bilgisi Eğitimi

\section{Makalenin Bilimdeki Özgünlüğü}

Ulusal alan yazında STEM eğitimi ile ilgili birçok çalışma yapılmıştır. Bu çalışmaların bir bütün halinde ve sistematik bir şekilde ortaya konulması, yapılacak yeni araştırmalar için alanda bulunan eksikliklerin görülmesini kolaylaştıracaktır. Ülkemizde STEM ile ilgili yapılan çalışmaların farklı değişkenler açısından incelendiği bazı çalışmalar bulunmaktadır (Daşdemir vd., 2018; Elmalı ve Balkan Kıyıcı, 2017; Kızılay, 2018). Bu çalışmalarda STEM eğitimi ile ilgili ortaya konulan makale ve lisansüstü tezlerin çok az bir kısmının araştırma kapsamına alındığı ve ülkemizde yapılan STEM eğitiminin şu anki durumunu (ya da eğilimini) ortaya koymada yeterli olmadığı görülmüştür. Bu çalışma ile alandaki bu eksiklik giderilmeye çalışılmıştır.

\section{Kaynaklar}

Açıkgöz, S. (2018). Fen eğitiminde okul öncesine yönelik yaklaşımlardan STEM ve Montessori yöntemlerinin öğretmen görüşleri doğrultusunda karşılaştırılması. Yayımlanmamış yüksek lisans tezi. Fen Bilimleri Enstitüsü Kastamonu Üniversitesi, Kastamonu.

Akgündüz, D., Aydeniz, M., Çakmakçı, G., Çavaş, B., Çorlu, M. S., Öner, T., Özdemir, S. (2015). STEM eğitimi Türkiye raporu: Günün modası mı yoksa gereksinim mi? [A report on STEM Education in Turkey: A provisional agenda or a necessity?][White Paper]. İstanbul Aydın Üniversitesi STEM Merkezi ve Eğitim Fakültesi.

Akgündüz, D., Ertepınar, H., Ger, A. M., Kaplan Sayı, A. ve Türk, Z. (2015). STEM eğitimi çalıştay raporu: Türkiye'de STEM eğitimi üzerine kapsamlı bir değerlendirme. İstanbul Aydın Üniversitesi STEM Merkezi ve Eğitim Fakültesi.

Alan, B. (2017). Fen bilgisi ögrretmen adaylarının bütünleşik öğretmenlik bilgilerinin desteklenmesi: STEM uygulamalarına hazırlama ĕgitimi. Yayımlanmamış yüksek lisans tezi. Eğitim Bilimleri Enstitüsü Frrat Üniversitesi, Elazığ.

Alıcı, M. (2018). Probleme dayalı öğrenme ortamında STEM eğitiminin tutum, kariyer algl ve meslek ilgisine etkisi ve ögrrenci görüşleri. Yayımlanmamış yüksek lisans tezi. Fen Bilimleri Enstitüsü Kırıkkale Üniversitesi, Kırıkkale.

Altaş, S. (2018). STEM eğitimi yaklaşımının sınıf öğretmeni adaylarının mühendislik tasarım süreçlerine, mühendislik ve teknoloji algllarına etkisinin incelenmesi. Yayımlanmamış yüksek lisans tezi. Fen Bilimleri Enstitüsü Muş Alparslan Üniversitesi, Muş. 
Arıkan, E. E. (2018). A theoretical study on stem education: proposal of two applications. Kuramsal Eğitimbilim Dergisi [Journal of Theoretical Educational Science], 11(1), 101-116.

Aşık, G., Doğança Küçük, Z., Helvacı, B ve Çorlu, M. S. (2017). Bütünleşik öğretmenlik projesi: öğretmen eğitimine sürdürülebilir bir yaklaşım. Turkish Journal of Education, 6(4), 200-215.

Aydın, G., Saka, M. ve Guzey, S. (2017). 4-8. sınıf öğrencilerinin fen, teknoloji, mühendislik, matematik (STEM=FeTeMM) tutumlarının incelenmesi. Mersin University Journal of the Faculty of Education, 13(2), 787-802.

Aygen, M. B. (2018). Fen bilgisi öğretmen adaylarının bütünleşik ögretmenlik bilgilerinin desteklenmesine yönelik STEM uygulamalart. Yayımlanmamış yüksek lisans tezi. Eğitim Bilimleri Enstitüsü Fırat Üniversitesi, Elazı̆̆.

Bahar, M., Yener, D., Yılmaz M., Emen, H. ve Gürer, F. (2018). 2018 fen bilimleri öğretim programı kazanımlarındaki değişimler ve fen teknoloji matematik mühendislik (STEM) entegrasyonu. Abant İzet Baysal Üniversitesi Eğitim Fakültesi Dergisi, 18(2), 702-735.

Bakırcı, H. ve Kutlu, E. (2018). Fen bilimleri öğretmenlerinin FeTeMM yaklaşımı hakkındaki görüşlerinin belirlenmesi. Türk Bilgisayar ve Matematik Eğitimi Dergisi, 9(2), 367-389.

Biçer, B. G. (2018). Fen bilimleri ögretmenlerinin STEM hakkındaki görüşlerinin bazı değişkenler açısında incelenmesi. Yayımlanmamış yüksek lisans tezi. Fen Bilimleri Enstitüsü Giresun Üniversitesi, Giresun.

Bilekyiğit, Y. (2018). Biyoloji dersinde gerçekleştirilen STEM etkinliğinin mesleki ve teknik anadolu lisesi ögrencilerinin kariyer ilgilerine etkisinin incelenmesi. Yayımlanmamış yüksek lisans tezi. Fen Bilimleri Enstitüsü Karamanoğlu Mehmetbey Üniversitesi, Karaman.

Bozan, M. A. (2018). Sınıf öğretmenlerinin STEM odaklı mesleki gelişim süreçleri: bir eylem araştırması. Yayımlanmamış yüksek lisans tezi. Eğitim Bilimleri Enstitüsü Eskişehir Osmangazi Üniversitesi, Eskişehir.

Ceylan, S. (2014). Ortaokul fen bilimleri dersindeki asitler ve bazlar konusunda fen, teknoloji, mühendislik ve matematik (FeTeMM) yaklaşımı ile öğretim tasarımı hazırlanmasına yönelik bir çalışma. Yayımlanmamış yüksek lisans tezi. Eğitim Bilimleri Enstitüsü Uludağ Üniversitesi, Bursa.

Çorlu, M. S., Capraro, R. M. ve Capraro, M. M. (2014). Introducing STEM education: 1mplications for educating our teachers for the age of innovation. Eğitim ve Bilim, 39(171), 74-85.

Çevik, M. (2017). Content analysis of STEM-focused education research in Turkey. Journal of Turkish Science Education, 14 (2), 12-26.

Çevik, M., Danıştay, A. ve Yağcı, A. (2017). Ortaokul öğretmenlerinin FeTeMM (fenteknoloji-mühendislik-matematik) farkındalıklarının farklı değişkenlere göre değerlendirilmesi. Sakarya University Journal of Education, 7(3), 584-599.

Çiftçi, M. (2018). Geliştirilen STEM etkinliklerinin ortaokul öğrencilerinin bilimsel yaratıcıllk düzeylerine, STEM disiplinlerini anlamalarına ve STEM mesleklerini fark etmelerine etkisi. Yayımlanmamış yüksek lisans tezi. Fen Bilimleri Enstitüsü Recep Tayyip Erdoğan Üniversitesi, Rize. 
Çolakoğlu, M. H. ve Günay Gökben, A. (2017). Türkiye'de eğitim fakültelerinde FeTeMM (STEM) çalışmaları. Informal Ortamlarda Araştırmalar Dergisi (İAD), 3, 46-69.

Damar, A., Durmaz, C. ve Önder, İ. (2017). Ortaokul öğrencilerinin FeTeMM uygulamalarına yönelik tutumları ve bu uygulamalara ilişkin görüşleri. Journal of Multidisciplinary Studies in Education, 1(1), 47-65.

Daşdemir, İ., Cengiz, E. ve Aksoy, G. (2018). Türkiye'de FeTeMM (STEM) eğitimi eğilim araştırması. YYÜ Eğitim Fakültesi Dergisi, 15(1), 1161-1183.

Dedetürk, A. (2018). 6. Sinıf ses konusunda FeTeMM yaklaşımı ile öğretim etkinliklerinin geliştirilmesi, uygulanması ve başarıya etkisinin araştırılması. Yayımlanmamış yüksek lisans tezi. Eğitim Bilimleri Enstitüsü Erciyes Üniversitesi, Kayseri.

Delen, İ. ve Uzun, S. (2018). Matematik öğretmen adaylarının FeTeMM temelli tasarladıkları öğrenme ortamlarının değerlendirilmesi. Hacettepe Üniversitesi Eğitim Fakültesi Dergisi, 33(3), 617-630.

Derin, G. (2017). Ortaöğretim matematik öğretmen ĕ̆itimi programına STEM entegrasyonu: bir ders örneği. Yayımlanmamış yüksek lisans tezi. Eğitim Bilimleri Enstitüsü Marmara Üniversitesi, İstanbul.

Deveci, İ. (2018). Fen bilimleri öğretmen adaylarının sahip oldukları FeTeMM farkındalıklarının girişimci özellikleri yordama durumu. Kastamonu Education Journal, 26(4), 1247-1256.

Doğanay, K. (2018). Probleme dayalı STEM etkinlikleriyle gerçekleştirilen bilim fuarlarının ortaokul ögrencilerinin fen bilimleri dersi akademik başarlarına ve fen tutumlarına etkisi. Yayımlanmamış yüksek lisans tezi. Fen Bilimleri Enstitüsü Kastamonu Üniversitesi, Kastamonu.

Dönmez, İ. (2017). STEM eğitimi çerçevesinde robotik turnuvalara yönelik öğrenci ve takım koçlarının görüşleri (bilim kahramanları buluşuyor örneği). Eğitim, Bilim ve Teknoloji Araştırmaları Dergisi, 2(1), 25-42.

Duygu, E. (2018). Simülasyon tabanlı sorgulayıcı öğrenme ortamında FeTeMM ĕgitiminin bilimsel süreç becerileri ve FeTeMM farkındalıklarına etkisi. Yayımlanmamış yüksek lisans tezi. Fen Bilimleri Enstitüsü Kırıkkale Üniversitesi, Kırıkkale.

Elmalı, Ş. ve Balkan Kıyıcı, F. (2017). Türkiye'de yayınlanmış FeTeMM eğitimi ile ilgili çalışmaların incelenmesi. Sakarya University Journal of Education, 7(3), 684-696.

Ensari, Ö. (2017). Öğretmen adaylarının FeTeMM eğitimi ve FeTeMM etkinlikleri hakkındaki görüşleri. Yayımlanmamış yüksek lisans tezi. Eğitim Bilimleri Enstitüsü Yüzüncü Yı1 Üniversitesi, Van.

Eroğlu, S. ve Bektaş, O. (2016). STEM eğitimi almış fen bilimleri öğretmenlerinin STEM temelli ders etkinlikleri hakkındaki görüşleri. Eğitimde Nitel Araştırmalar Dergisi, 4(3), 43-67.

Gazioğlu, T. (2018). STEM uygulamalarının 7. Sınıf öğrencilerinin kuvvet ve enerji ünitesindeki başartlarına ve fen bilimleri dersine karşı tutumlarına etkisinin incelenmesi. Yayımlanmamış yüksek lisans tezi. Fen Bilimleri Enstitüsü Kastamonu Üniversitesi, Kastamonu. 
Genek, S. E. (2018). STEM ĕgitimi uygulanan ilkokul öğrencilerinin bilimsel yaratıcılık düzeylerinin incelenmesi. Yayımlanmamış yüksek lisans tezi. Eğitim Bilimleri Enstitüsü Bahçeşehir Üniversitesi, İstanbul.

Girgin, Ş. (2018). Erken STEM ĕgitiminin etnografik durum çalışması: öğrencilerin otantik ögrenme deneyimlerinin incelenmesi. Yayımlanmamış yüksek lisans tezi. Fen Bilimleri Enstitüsü Y1ldız Teknik Üniversitesi, İstanbul.

Gökbayrak, S. (2017). Fen, teknoloji, mühendislik ve matematik (STEM) uygulamalarının fen bilgisi ögretmen adaylarının STEM farkındalık düzeyleri, entegre STEM ögretimi yönelimi ve bilimsel süreç becerilerine etkisinin incelenmesi. Yayımlanmamış yüksek lisans tezi. Eğitim Bilimleri Enstitüsü Yüzüncü Yıl Üniversitesi, Van.

Gökbayrak, S. ve Karışan, D. (2017). STEM etkinliklerinin fen bilgisi öğretmen adaylarının bilimsel süreç becerilerine etkisi, Batı Anadolu Ĕgitim Bilimleri Dergisi, 8(2), 63-84.

Güder, Y. ve Gürbüz, R. (2018). STEM eğitimine geçişte bir araç olarak disiplinler arası matematiksel modelleme oluşturma etkinlikleri: öğretmen ve öğrenci görüşleri. Adryaman University Journal of Educational Sciences, 2018, Special Issue, 171-199.

Gülen, S. ve Yaman, S. (2018). Fen bilimleri dersinde argümantasyon süreci ve STEM disiplinlerinin kullanımı; odak grup görüşmesi. YYÜ Ĕ̈itim Fakültesi Dergisi (YYU Journal of Education Faculty), 15(1), 1184-1211.

Gülgün, C., Yılmaz, A. ve Çağlar, A. (2017). Fen bilimleri dersinde uygulanan STEM etkinliklerinde bulunması gereken nitelikler hakkında öğretmen görüşleri. Journal of Current Researches on Social Sciences 7(1), 459-478.

Gülhan, F. (2016). Fen-teknoloji-mühendislik-matematik entegrasyonunun (STEM) 5.sınıf ögrencilerinin algl, tutum, kavramsal anlama ve bilimsel yaratıcılıklarına etkisi. Yayımlanmamış yüksek lisans tezi. Eğitim Bilimleri Enstitüsü Marmara Üniversitesi, İstanbul.

Gülhan, F. ve Şahin, F. (2018). Niçin STEM eğitimi?: ortaokul 5. sınıf öğrencilerinin STEM alanlarındaki kariyer tercihlerinin incelenmesi. Journal Of STEAM Education Bilim, Teknoloji, Mühendislik, Matematik ve Sanat Eğitimi Dergisi, 1(1), 1-23.

Günbatar, M. S. ve Bakırc1, H. (2019). STEM teaching intention and computational thinking skills of pre-service teachers. Education and Information Technologies. 1615-1629.

Güven, Ç., Selvi, M. ve Benzer, S. (2018). 7E öğrenme modeli merkezli STEM etkinliğine dayalı öğretim uygulamalarının akademik başarıya etkisi. Anemon Muş Alparslan Üniversitesi Sosyal Bilimler Dergisi, 6(STEMES’18), 73-80.

Hacığlu, Y. (2017). Fen, teknoloji, mühendislik ve matematik (STEM) eğitimi temelli etkinliklerin fen bilgisi ögretmen adaylarının eleştirel ve yaratıcı düşünme becerilerine etkisi. Yayımlanmamış doktora tezi. Eğitim Bilimleri Enstitüsü Gazi Üniversitesi, Ankara.

Hacıoğlu, Y., Yamak, H. ve Kavak, N. (2016). Mühendislik tasarım temelli fen eğitimi ile ilgili öğretmen görüşleri. Bartın Üniversitesi Eğitim Fakültesi Dergisi, 5(3), 807-830.

Haciömeroğlu, G. ve Bulut, A. S. (2016). Entegre FeTeMM öğretimi yönelim ölçeği Türkçe formunun geçerlik ve güvenirlik çalışması. Eğitimde Kuram ve Uygulama, 12(3), 654669. 
Herdem, K., ve Ünal, İ. (2018). STEM eğitimi üzerine yapılan çalışmaların analizi: bir metasentez çalışması. Marmara Üniversitesi Atatürk Eğitim Fakültesi Eğitim Bilimleri Dergisi, 48(48).

Irkıçatal, Z. (2016). Fen, teknoloji, mühendislik ve matematik (FeTeMM) içerikli okul sonrası etkinliklerin ögrencilerin başarılarına ve FeTeMM algılart üzerine etkisi. Yayımlanmamış yüksek lisans tezi. Eğitim Bilimleri Enstitüsü Akdeniz Üniversitesi, Antalya.

İnce, K., Mısır, M. E., Küpeli, M. A. ve Fırat, A. (2018). 5. sınıf fen bilimleri dersi yer kabuğunun gizemi ünitesinin öğretiminde STEM temelli yaklaşımın öğrencilerin problem çözme becerisi ve akademik başarısına etkisinin incelenmesi. Journal of STEAM Education - Bilim, Teknoloji, Mühendislik, Matematik ve Sanat Eğitimi Dergisi, 1(1), 64-78.

Kalkan, Ç. ve Eroğlu, S. (2017). Destek eğitim odalarında üstün/özel yetenekli öğrenciler için STEM materyallerine dayalı örnek etkinliklerin tasarlanması. Üstün Zekâlılar Eğitimi ve Yaratıcılık Dergisi, 4(2), 36-46.

Karakaş, A. (2017). Fen-teknoloji-mühendislik-matematik (STEM) uygulamalarının fen ögretimine yansımaları. Yayımlanmamış doktora tezi. Eğitim Bilimleri Enstitüsü Pamukkale Üniversitesi, Denizli.

Karakaya, F. (2017). Ortaokul öğrencilerinin fen, teknoloji, mühendislik ve matematik (FeTeMM) mesleklerine yönelik ilgi düzeyleri. Yayımlanmamış yüksek lisans tezi. Fen Bilimleri Enstitüsü Kahramanmaraş Sütçü İmam Üniversitesi, Kahramanmaraş.

Karakaya, F., Avgın, S. S. ve Yılmaz, M. (2018). Ortaokul öğrencilerinin fen-teknolojimühendislik-matematik (FeTeMM) mesleklerine olan ilgileri. Ihlara Ĕ̈itim Araştırmaları Dergisi (IHEAD) 3(1), 36-53.

Karakaya, F., Ünal, A., Çimen, O. ve Yılmaz, M. (2018). Fen bilimleri öğretmenlerinin STEM yaklaşımına yönelik farkındalıkları. Eğitim ve Toplum Araştırmaları Dergisi/JRES, 5(1), 124-138.

Karakuş, M. ve Us, M. (2013). İlköğretim 4. sınıf fen ve teknoloji programından yansımalar “Adana ili örneği”. Ondokuz Mayıs Üniversitesi Ĕgitim Fakültesi Dergisi, 32(2), 197222.

Karc1, M. (2018). 5. Sinıf elektrik ünitesinin ögrretiminde kullantlan STEM etkinliklerine dayalı senaryo tabanlı öğrenme yaklaşımının (STÖY) öğrencilerin akademik başarı, STEM disiplinlerine dayalı meslek seçmeye olan ilgisi ve fen öğrenmeye yönelik motivasyonlarına olan etkisi. Yayımlanmamış yüksek lisans tezi. Sosyal Bilimler Enstitüsü Çukurova Üniversitesi, Adana.

Karışan, D. ve Yurdakul, Y. (2017). Mikroişlemci destekli fen-teknoloji-mühendislik matematik (STEM) uygulamalarının 6. sınıf öğrencilerinin bu alanlara yönelik tutumlarına etkisi. Adnan Menderes Üniversitesi Eğitim Fakültesi Ĕgitim Bilimleri Dergisi, 8(1), 37-52.

Kayalar, A. (2018). Mobil teknolojiye dayalı FeTeMM uygulamalarının öğretmen adaylarının mühendislik tasarım becerilerine, sistem düşünme zekâsına ve ögretmenlik özyeterliklerine etkisi. Yayımlanmamış yüksek lisans tezi. Eğitim Bilimleri Enstitüsü Dokuz Eylül Üniversitesi, İzmir. 
Kılınç, S. (2018). Exploring of STEM readiness of a faculty of education in Turkey. Yayımlanmamış yüksek lisans tezi. Fen Bilimleri Enstitüsü Orta Doğu Teknik Üniversitesi, Ankara.

Kızılay, E. (2018). Türkiye'de öğretmen eğitimi konusundaki STEM çalışmaları. Tarih Okulu Dergisi (TOD), Y11 11, Say1 XXXIV, 1201-1226

Koç, Y. (2017). Fen bilimleri dersinde STEM eğitim modeli yaklaşımı kullanarak genç mekatronikcilerin yetiştirilmesi. Yayımlanmamış yüksek lisans tezi. Fen Bilimleri Enstitüsü İstanbul Gelişim Üniversitesi, İstanbul.

Korkut Owen, F. ve Eraslan Çapan, B. (2018a). Fen, teknoloji, matematik ve mühendislik alanlarını seçmeyi planlama: meslek seçimine ilişkin inançlar. Hacettepe Üniversitesi Ĕ̈itim Fakültesi Dergisi, 33(4), 915-933.

Korkut Owen, F. ve Eraslan Çapan, B. (2018b). Fen, teknoloji, matematik ve mühendislik alanları: seçmek ya da seçmemek. AJESI - Anadolu Journal of Educational Sciences International, 8(1), 1-32.

Koyunlu Ünlü, Z. ve Dökme, İ. (2016). Özel yetenekli öğrencilerin FeTeMM’in mühendisliği hakkındaki imajları. Trakya Üniversitesi Eğitim Fakültesi Dergisi, 7(1), 196-204.

MEB. (2016). STEM eğitimi raporu. Ankara: Yenilik ve Eğitim Teknolojileri Genel Müdürlüğü.

MEB. (2018). Dünyada eğitim trendleri ve ülkemizde STEM öğrenme etkinlikleri: MEB K12 okulları örneği. Ankara: Yenilik ve Eğitim Teknolojileri Genel Müdürlüğü.

National Academy of Engineering (NAE)\&National Research Council (NRC) (2014). STEM integration in K-12 education: Status, prospects, and an agenda for research. Washington, DC: The National Academies Press.

Ocak, M. H. (2017). Öğrencilerin STEM'e ilişkin tutumlart ve kariyer tercihleri ile ilişkilerinin incelenmesi. Yayımlanmamış yüksek lisans tezi. Eğitim Bilimleri Enstitüsü Yeditepe Üniversitesi, İstanbul.

Öcal, S. (2018). Okul öncesi eğitime devam eden 60-66 ay çocuklarına yönelik geliştirilen STEM programının çocukların bilimsel süreç becerilerine etkisinin incelenmesi. Yayımlanmamış yüksek lisans tezi. Sosyal Bilimler Enstitüsü Yıldız Teknik Üniversitesi, İstanbul.

Öner, A.T. ve Capraro, R.M. (2016). FeTeMM okulu olmak iyi öğrenci başarısı anlamına mı gelir?. Ĕ̈itim ve Bilim, 41(185), 1-17.

Öner, A.T., Capraro, R.M. ve Capraro, M.M. (2016). The effect of T-STEM designation on charter schools: a longitudinal examination of students' mathematics achievement. Sakarya University Journal of Education, 6(2), 80-96.

Özbilen, A. G. (2018). STEM eğitimine yönelik öğretmen görüşleri ve farkındalıkları. Scientific Educational Studies, 2(1), 1-21.

Özçelik, A. (2017). Üstün/özel yetenekli öğrenciler için okul dışı STEM eğitiminin değerlendirilmesi. Yayımlanmamış yüksek lisans tezi. Sosyal Bilimler Enstitüsü İstanbul Aydın Üniversitesi, İstanbul.

Özkan, C. ve Çepni, S. (2018). Elektrik akımı ile oluşturulan yapay duygular: bir STEM öyküsü ve yarattığı eğitim potansiyeli. Fen, Matematik, Girişimcilik ve Teknoloji Ĕ̈itimi Dergisi 1(1), 89-107. 
Öztürk, M. (2017). İlkokul 4. Sinıf öğretmenleri ve öğrencilerinin FeTeMM ĕgitimine ilişkin yeterlik inançları ve tutumlarının incelenmesi. Yayımlanmamış yüksek lisans tezi, Sosyal Bilimler Enstitüsü Ege Üniversitesi, İzmir.

Parlakay, E. S. (2017). FeTeMM (STEM) uygulamalarının beşinci sınıf öğrencilerinin sorgulayıcı ögrenmelerine, motivasyonlarına ve 'canlılar dünyasını gezelim ve tanıyalım' ünitesindeki akademik başarılarına etkisi. Yayımlanmamış yüksek lisans tezi, Fen Bilimleri Enstitüsü Mustafa Kemal Üniversitesi, Hatay.

Pekmez, E., Yılmaz, H., Alaçam Akşit, A. C. ve Güler, F. (2018). İlköğretim öğrencilerinin fen-teknoloji-tasarım süreci ile ilgili becerilerinin geliştirilmesi üzerine bir eğitim modülü uygulamas1. Ege Eğitim Dergisi / Ege Journal of Education, 19(1), 135-160.

Poyraz, G. T. (2018). STEM eğitimi uygulamasında kayseri ili örneğinin incelenmesi ve uzaktan STEM eğitiminin uygulanabilirliği. Yayımlanmamış yüksek lisans tezi, Sosyal Bilimler Enstitüsü Anadolu Üniversitesi, Eskişehir.

Saçan, E. (2018). Bilim uygulamaları dersi için FeTeMM merkezli bir öğretim programı önerisi ve etkililiği. Yayımlanmamış doktora tezi. Eğitim Bilimleri Enstitüsü Hacettepe Üniversitesi, Ankara.

Sarı, Z. (2017). Dil öğrenimi hakkındaki inançlar ile yabancı dil sınıf kaygısı arasındaki ilişki: Türkiye'deki üniversitelerde ĕ̆itim dili Ingilizce olan FeTeMM bölümleri. Yayımlanmamış yüksek lisans tezi. Sosyal Bilimler Enstitüsü Kafkas Üniversitesi, Kars.

Sarıcan, G. (2017). Bütünleşik STEM eğitiminin akademik başarıya, problem çözmeye yönelik yansitıcı düşünme becerisine ve ögrenmede kalıcılı̆̆a etkisi. Yayımlanmamış yüksek lisans tezi. Sosyal Bilimler Enstitüsü İstanbul Aydın Üniversitesi, İstanbul.

Seren, S. ve Veli, E. (2018). 2005 y1lı itibariyle değişen fen bilimleri dersi öğretim programlarında STEM eğitimine yer verilme düzeylerinin karşılaştırılması. Journal Of STEAM Education-Bilim, Teknoloji, Mühendislik, Matematik ve Sanat Eğitimi Dergisi, 1(1), $24-47$.

Şahin, A., Erdoğan, N., Morgan, J., Capraro, M.M. ve Capraro, R. M. (2012). The effects of high school course taking and sat scores on college major selection. Sakarya University Journal of Education, 2(3), 96-109.

Şahin, E. ve Kabasakal, V. (2018). STEM eğitim yaklaşımında dinamik matematik programlarının (Geogebra) kullanımına yönelik öğrenci görüşlerinin incelenmesi. Anemon Muş Alparslan Üniversitesi Sosyal Bilimler Dergisi, 6(STEMES’18) 55-62.

Şatgeldi, A. N. (2017). Fen öğretmenlerinin STEM ĕgitimindeki hazırbulunuşlukları hakkındaki algılarını ölçmek için test geliştirme çalışması. Yayımlanmamış yüksek lisans tezi. Fen Bilimleri Enstitüsü Orta Doğu Teknik Üniversitesi, Ankara.

Şen, C. (2018). Öğretmen adaylarının entegre FeTeMM ögrretimine yönelimlerinin ve teknolojiye yönelik tutumlarının farklı değişkenler açısından incelenmesi. Yayımlanmamış yüksek lisans tezi. Eğitim Bilimleri Enstitüsü Çanakkale Onsekiz Mart Üniversitesi, Çanakkale.

Şentürk, F. K. (2017). FeTeMM etkinliklerinin fen bilimleri dersindeki kavramsal anlama ve bilimsel yaratıcılık üzerindeki etkileri ve ögrenci görüşleri. Yayımlanmamış yüksek lisans tezi. Eğitim Bilimleri Enstitüsü Sıtkı Koçman Üniversitesi, Muğla. 
Tabar, V. (2018). Ülkemizde FeTeMM alanında yapılmış olan çalışmaların içerik analizi. Yayımlanmamış yüksek lisans tezi, Eğitim Bilimleri Enstitüsü Yüzüncü Y1l Üniversitesi, Van.

Tabaru, G. (2017). İlkokul 4. Sinıf ögrencilerine fen bilimleri dersinde uygulanan STEM temelli etkinliklerin çeşitli değişkenlere etkisi. Yayımlanmamış yüksek lisans tezi. Eğitim Bilimleri Enstitüsü Ömer Halisdemir Üniversitesi, Niğde.

Tantu, Ö. (2017). STEM eğitimi kapsamında kullanılan mobil uygulamaların öğretmenler ile değerlendirilmesi. Yayımlanmamış yüksek lisans tezi. Sosyal Bilimler Enstitüsü Orta Doğu Teknik Üniversitesi, Ankara.

Taştan Akdağ, F. (2017). STEM uygulamalarının öğrencilerin akademik başarı, bilimsel süreç ve yaşam becerileri üzerine etkisi. Yayımlanmamış doktora tezi. Eğitim Bilimleri Enstitüsü Ondokuz Mayıs Üniversitesi, Çanakkale.

Tekerek, M. \& Tekerek, B. (2018). Integrated İnstructional material and development processes. Turkish Journal of Education, 7(3), 156-168.

Tezel, Ö. ve Yaman, H. (2017). FeTeMM eğitimine yönelik Türkiye'de yapılan çalışmalardan bir derleme. Ĕgitim ve Öğretim Araştırmaları Dergisi, 6(1), 135-145.

Tezsezen, S. (2017). Öğretmen adaylarının FeTeMM farkındalıklarının FeTeMM alanları tanımları ve ilişkileri üzerinden incelenmesi. Yayımlanmamış yüksek lisans tezi. Fen Bilimleri Enstitüsü Boğaziçi Üniversitesi, İstanbul.

Timur, B. ve İnançlı, E. (2018). Fen bilimleri öğretmen ve öğretmen adaylarının STEM eğitimi hakkındaki görüşleri. Uluslararası Bilim ve Eğitim Dergisi-International Journal Of Science And Education, 1(1), 48-66.

TÜSİAD. (2014). STEM (science, technology, engineering and mathematics fen, teknoloji, mühendislik, matematik) alanında ĕgitim almış işgücüne yönelik talep ve beklentiler araştırması. İstanbul: TÜSİAD.

Tüzün, Ü. N. ve Tüysüz, M. (2018). Özel yetenekli bireylerin öğretmenleri için STEAM eğitimi. Türk Üstün Zekâ ve Eğitim Dergisi,8(1), 16-32.

Uğraş, M. ve Genç, Z. (2018). Investigating preschool teacher candidates' STEM teaching 1ntention and the views about STEM education. Bartın Üniversitesi Eğitim Fakültesi Dergisi, 7(2), 724-744.

Üçüncüoğlu, İ. ve Bozkurt Altan, E. (2018). Fen Bilimleri Öğretmen Adayları için STEM Odaklı Laboratuvar Uygulamaları: "Sağlıklı Yaşam" Etkinliği. International Journal of Humanities and Education, 329-347.

Yakman, G., \& Lee, H. (2012). Exploring the exemplary STEAM education in the US as a practical educational framework for Korea. Journal of the korean Association for Science Education, 32(6), 1072-1086. DOI: 10.14697/jkase.2012.32.6.1072.

Yaman, C., Özdemir, A. ve Akar Vural, R. (2018). STEM uygulamaları öğretmen öz-yeterlik ölçeğinin geliştirilmesi: bir geçerlik ve güvenirlik çalışması. Adnan Menderes Üniversitesi, Sosyal Bilimler Enstitüsü Dergisi, 5(2), 93-104.

Yıldırım, A. ve Şimşek, H. (2016). Sosyal Bilimlerde Nitel Araştırma Yöntemleri. Ankara: Seçkin Akademik ve Mesleki Yayınları. 
Yıldırım, B. (2016). 7. Sınıf fen bilimleri dersine entegre edilmiş fen teknoloji mühendislik matematik (STEM) uygulamalarl ve tam ögrenmenin etkilerinin incelenmesi. Yayımlanmamış doktora tezi. Eğitim Bilimleri Enstitüsü Gazi Üniversitesi, Ankara.

Yıldırım, B. (2018). Bağlam temelli öğrenmeye uygun olarak hazırlanmış STEM uygulamalarının etkilerinin incelenmesi. Atatürk Üniversitesi Kazım Karabekir Ĕ̈itim Fakültesi Dergisi, 1-20.

Yıldırım, B. ve Selvi, M. (2017). STEM uygulamaları ve tam öğrenmenin etkileri üzerine deneysel bir çalışma. Journal of Theory and Practice in Education / Ĕgitimde Kuram ve Uygulama, 13(2), 183-210.

Yıldırım, B. ve Selvi, M. (2018). Ortaokul öğrencilerinin STEM uygulamalarına yönelik görüşlerinin incelenmesi. Anemon Muş Alparslan Üniversitesi Sosyal Bilimler Dergisi, 6(STEMES’18) 47-54.

Yıldırım, B. ve Türk, C. (2018). Sınıf öğretmeni adaylarının STEM eğitimine yönelik görüşleri: uygulamalı bir çalışma. Trakya Üniversitesi Eğitim Fakültesi Dergisi, 8(2), 195-213.

Yıldırım, P. (2017). Fen, teknoloji, mühendislik ve matematik (STEM) entegrasyonuna ilişkin nitel bir çalışma. Atatürk Üniversitesi Kazım Karabekir Eğitim Fakültesi Dergisi, (35), 31-55.

Yılmaz, H., Yiğit Koyunkaya, M., Güler, F. ve Güzey, S. (2017). Fen, teknoloji, mühendislik, matematik (STEM) eğitimi tutum ölçeğinin Türkçeye uyarlanması. Kastamonu Eğitim Dergisi, 25(5), 1787-1800.

\section{Summary}

\section{Statement of Problem}

STEM is an acronym that formed from a combination of the initials of science, technology, engineering and mathematics in its original language. It is an interdisciplinary educational approach that aims to provide students with skills such as communication, teamwork, creative thinking, research, inquiry, production and solving everyday life problems by integrating the knowledge and skills covered by the fields of science, technology, mathematics and engineering. By addressing these areas in a connected way, it is aimed both to create meaningful learning and to obtain the highest efficiency from the educational process.

STEM education first emerged in the United States. The aim of STEM education in A12 in the United States is to increase advanced education and career fields in STEM fields, to improve the workforce with STEM skills and to increase science literacy in all students (Öztürk, 2017). 21. the United States, which wants to maintain its leadership in the world throughout the century, attaches a separate importance to the STEM schools established for this purpose and to the STEM school system that houses these schools (Akgündüz, Aydeniz et al. 2015). 
In the last decades, STEM education has gained great importance and is a topic discussed internationally. South Korea has created Steam by adding art to the areas covered by STEM education, unlike America (Çiftçi, 2018).

Turkey does not have a strategic action plan prepared by the Ministry of Education for STEM education. However, in the 2015-2019 Strategic Plan, the objectives for strengthening STEM were included (MEB, 2018). For this purpose, many studies about STEM education have been made in the national literature. It was determined that these studies increased after 2014. These studies indicate that STEM education in Turkey has increased with each passing day the importance of the integration and expansion of the STEM's of course.

This research, Turkey in STEM education related done master theses and articles from some of the variables in terms of examination and in our country, the overall situation of the studies in this area (or trend) aims to put forward. STEM education be made about the content of their work in Turkey, it was carried out to determine the least studied areas and to demonstrate the point that is missing in the literature. The findings obtained from this study are intended as a guide in the light of the work done in Turkey. The aim of this research is to provide information about the content of STEM education studies conducted in Turkey, to identify the areas under study and to identify the missing points in the literature. It is intended to be a guide to the studies conducted in Turkey in the light of the findings from the research.

\section{Method}

In this study, one of the qualitative research methods, document review method was used. With this method, articles and post graduate theses about STEM education were examined in the national literature between 2010 and 2018.

A total of 45 graduate theses containing the terms "STEM, STEM education, FeTeMM, integrated STEM teaching” were examined in the data base of YÖK National thesis center during the survey of graduate theses. Accessibility conditions of theses are given in Table 1. In the selection of the articles, 64 educational journals are listed in the TUBITAK ULAKBIM-Journal Park database. Within these journals, 52 articles in 38 journals have been included in the scope of research. The distribution of the articles according to the published journals is given in Table 2 .

Data from the studies were analyzed using descriptive analysis technique from the types of analysis used in qualitative research. Studies included in the scope of research, type of research, availability of theses, distribution of thesis advisors by academic title, distribution of theses by universities, distribution of research by year, dependent variables studied, 
research model used, used data collection tools, the sample groups studied, data analysis method used were examined and analyzed.

\section{Findings}

The descriptive information of the studies in STEM education in Turkey is examined, between the years 2010-2018 39 master thesis, 52 articles, and six doctoral dissertations, were a total of 97 academic work.

When the distribution of the studies by year was examined, it was determined that 21 of the theses were prepared in 2018, 20 in 2017, three in 2016 and one in 2014. Of the articles, one belongs to 2012, one in 2013, one in 2014, six in 2016, 15 in 2017, and 28 in 2018.

When the distribution of the advisors according to the academic title is examined, it is seen that 16 of the advisors who carry out the STEM-related theses have the academic title of associate professor, 14 of them are doctor faculty members and 11 of them are professors.

When the universities where the theses were conducted were examined, 45 graduate theses were carried out within 34 different universities. Three theses related to STEM were given at Kastamonu University and Middle East Technical University.

The most studied dependent variable in research has been found to be skill. Among the skills, most studied scientific process skills have been. The second most studied dependent variable was attitude. It was observed that in the most of the studies were used quantitative research methods.

It was observed that the most widely used data collection tool in the researchs examined is Scales. A total of 74 scales were used in the researchs. Among these scales, it is to the most attitude scales $(n=19)$ were used. 87 different data collection tools were used in the researchs.

The study was conducted with the most students as a sample group (44.2\%). In these studies conducted with students, it is pointed out that they are mostly working with middle school students, while they are working few with pre-school children. The second most studied sample group was teachers with a rate of $26.2 \%$. Most studies were conducted with science teachers.

The researchs examined showed that parametric tests were used most often in data analysis. The most commonly used test among parametric tests is the $T$ test $(n=27)$. The second most commonly used method in data analysis is content analysis $(n=38)$. 


\section{Discussion and Conclusion}

As a result of the studies conducted on STEM, it was revealed that the number of studies differed by years. It has been determined that the most studies related to STEM education in our country since 2010 were conducted in 2018. No post graduate thesis prior to 2014 was found in the national literature. It is thought that changes to the Science Teaching Program in 2014 were instrumental in the emergence of this situation.

With this study was examined 64 educational journals in TUBITAK-ULAKBIM DergiPark database. As of 2010, 1119 editions of these journals have been scanned and a total of 13313 articles have been published in these editions. Among these articles, it was determined that the keywords employed were found in 54 articles published in only 38 journals.

When the studies were examined, mostly quantitative research methods were used to study the effects of STEM education on attitude, scientific process skills and success. It is thought that quantitative research method is used more because it provides various possibilities for practitioners and gives more objective results.

The most widely used method of data analysis in researchs is the T-test from parametric tests. Common use of the $t$ test for the analysis of data is due to the greater preference of the quantitative research method in researchs.

In this study, the sample group consists mostly of Secondary School students and it is thought that the unit and subject areas in the secondary science curriculum are more suitable for using STEM approach.

With this research has been discussed the impact of STEM applications on scientific process skills, problem solving skills, academic achievement, self-sufficiency, creativity, levels of scientific creativity, engineering design skills, motivation, STEM awareness and STEM perceptions. 